\title{
Regional climate downscaling over Europe: perspectives from the EURO-CORDEX community
}

\author{
Daniela Jacob ${ }^{1}$. Claas Teichmann ${ }^{1}$ (D) - Stefan Sobolowski ${ }^{2}$ Eleni Katragkou ${ }^{3}$. Ivonne Anders ${ }^{4} \cdot$ Michal Belda $^{5}$. \\ Rasmus Benestad $^{6}$. Fredrik Boberg ${ }^{7}$. Erasmo Buonomo $^{8,9} \cdot$ Rita M. Cardoso $^{10}$ - Ana Casanueva ${ }^{11}$. \\ Ole B. Christensen ${ }^{7}$. Jens Hesselbjerg Christensen ${ }^{2,12}$. Erika Coppola ${ }^{13}$. Lesley De Cruz ${ }^{14}$. Edouard L. Davin ${ }^{15}$. \\ Andreas Dobler ${ }^{6}$. Marta Domínguez ${ }^{16} \cdot$ Rowan Fealy $^{17}$. Jesus Fernandez ${ }^{11}$. Miguel Angel Gaertner ${ }^{18}$. \\ Markel García-Díez ${ }^{11}$ • Filippo Giorgi ${ }^{13}$. Andreas Gobiet ${ }^{4}$. Klaus Goergen ${ }^{19,20}$ • Juan José Gómez-Navarro ${ }^{21}$. \\ Juan Jesús González Alemán ${ }^{18}$. Claudia Gutiérrez ${ }^{18}$. José M. Gutiérrez ${ }^{22}$ • Ivan Güttler ${ }^{23}$ • Andreas Haensler ${ }^{1}$. \\ Tomáš Halenka $^{5}$. Sonia Jerez ${ }^{21}$ • Pedro Jiménez-Guerrero ${ }^{21}$ - Richard G. Jones ${ }^{8} \cdot$ Klaus Keuler $^{24}$ • Erik Kjellström ${ }^{25}$. \\ Sebastian Knist ${ }^{20,26}$. Sven Kotlarski ${ }^{27}$. Douglas Maraun ${ }^{28}$. Erik van Meijgaard ${ }^{29}$ - Paola Mercogliano ${ }^{30,31}$. \\ Juan Pedro Montávez ${ }^{21}$. Antonio Navarra ${ }^{30}$. Grigory Nikulin ${ }^{25}$. Nathalie de Noblet-Ducoudré ${ }^{32}$. \\ Hans-Juergen Panitz ${ }^{33}$. Susanne Pfeifer ${ }^{1} \cdot$ Marie Piazza $^{28} \cdot$ Emanuela Pichelli $^{13}$. Joni-Pekka Pietikäinen ${ }^{1,34}$. \\ Andreas F. Prein ${ }^{35}$. Swantje Preuschmann ${ }^{1}$. Diana Rechid ${ }^{1}$ - Burkhardt Rockel ${ }^{36}$ - Raquel Romera ${ }^{17}$. \\ Enrique Sánchez ${ }^{17} \cdot$ Kevin Sieck $^{1} \cdot$ Pedro M. M. Soares ${ }^{10} \cdot$ Samuel Somot $^{37} \cdot$ Lidija Srnec $^{23} \cdot$ Silje Lund Sørland $^{15}$. \\ Piet Termonia ${ }^{14,38} \cdot$ Heimo Truhetz $^{28} \cdot$ Robert Vautard $^{32} \cdot$ Kirsten Warrach-Sagi $^{39} \cdot$ Volker Wulfmeyer $^{39}$
}

Received: 17 May 2019 / Accepted: 13 November 2019 / Published online: 23 April 2020

(C) The Author(s) 2020

\begin{abstract}
The European CORDEX (EURO-CORDEX) initiative is a large voluntary effort that seeks to advance regional climate and Earth system science in Europe. As part of the World Climate Research Programme (WCRP) - Coordinated Regional Downscaling Experiment (CORDEX), it shares the broader goals of providing a model evaluation and climate projection framework and improving communication with both the General Circulation Model (GCM) and climate data user communities. EURO-CORDEX oversees the design and coordination of ongoing ensembles of regional climate projections of unprecedented size and resolution ( $0.11^{\circ}$ EUR-11 and $0.44^{\circ}$ EUR-44 domains). Additionally, the inclusion of empiricalstatistical downscaling allows investigation of much larger multi-model ensembles. These complementary approaches provide a foundation for scientific studies within the climate research community and others. The value of the EUROCORDEX ensemble is shown via numerous peer-reviewed studies and its use in the development of climate services. Evaluations of the EUR-44 and EUR-11 ensembles also show the benefits of higher resolution. However, significant challenges remain. To further advance scientific understanding, two flagship pilot studies (FPS) were initiated. The first investigates local-regional phenomena at convection-permitting scales over central Europe and the Mediterranean in collaboration with the Med-CORDEX community. The second investigates the impacts of land cover changes on European climate across spatial and temporal scales. Over the coming years, the EURO-CORDEX community looks forward to closer collaboration with other communities, new advances, supporting international initiatives such as the IPCC reports, and continuing to provide the basis for research on regional climate impacts and adaptation in Europe.
\end{abstract}

Keywords EURO-CORDEX $\cdot$ CORDEX $\cdot$ Climate change $\cdot$ Regional climate models $\cdot$ Regional climate modelling

Daniela Jacob

daniela.jacob@hzg.de

Extended author information available on the last page of the article.

\section{Introduction}

The World Climate Research Programme (WCRP) established the Task Force for Regional Climate Downscaling (TFRCD) in 2009, which created the Coordinated Regional 
climate Downscaling Experiment (CORDEX) initiative to advance and coordinate the science and application of regional climate downscaling through global partnerships (Giorgi et al. 2009). The major goals of CORDEX are as follows: (i) to better understand relevant regional/local climate phenomena, their variability and changes, through downscaling, (ii) to evaluate and improve regional climate downscaling models and techniques, (iii) to produce coordinated sets of regional downscaled projections worldwide, and (iv) to foster communication and knowledge exchange with users of regional climate information. Working towards these goals also helps address WCRP Grand Challenges such as: Water for the food baskets of the world, Clouds circulation and climate sensitivity, Weather and climate extremes, Carbon feedbacks in the climate system, Melting ice and global consequences, and Regional sea-level change and coastal impacts. CORDEX was recently added as a major project under the WCRP auspices and is also included as a diagnostic Model Intercomparison Project (MIP) in CMIP6 (Gutowski et al. 2016). Each regional team can coordinate its own simulations and associated research activities. The EURO-CORDEX community, in particular, has established itself as a key contributor to CORDEX, with more than 30 modelling groups collaborating in the simulation of the European climate, across all scenarios, and making the regional climate model (RCM) data publicly available and accessible in particular via the Earth System Grid Federation (ESGF). Further, many of the groups in the EURO-CORDEX community have contributed with a wide range of simulations of regional climates in other CORDEX regions and have played an instrumental role in defining standards for the ESGF publication.

This community is organized in a way that allows both a high level of coordination as well as flexibility (e.g., dynamic structures to address emergent scientific challenges). EURO-CORDEX celebrated 10 years as an active consortium in 2019. The scientific output along with the substantial contributions to open archives (e.g., Earth System Grid Federation, https://esgf.llnl.gov) marks EURO-CORDEX as a success. However, Europe enjoys many financial and institutional advantages compared with other regions that should not be ignored. Despite this, there are many aspects to EURO-CORDEX's success that do not rely on these advantages but rather on the members' commitment to a strongly coordinated, organized and community-based effort. The authors hope that the lessons learned from the experience of the EURO-CORDEX community can be applied as a model for other CORDEX regions as they evolve.

EURO-CORDEX is driven by scientific challenges, aligned with the first two goals of the WCRP-CORDEX initiative. EURO-CORDEX has made substantial progress in addressing the following specific challenges:

- Added value of regional downscaling with respect to scale, uncertainty, processes, and phenomena (Torma et al. 2015; Giorgi and Gutowski 2015; Prein and Gobiet 2016; Fantini et al. 2018; Coppola et al. 2018a; Soares and Cardoso 2017).

- Impacts of coupled processes and land-atmosphere (LA) feedbacks in a regional context, Knist et al. (2017) and Davin et al. (2020).

- Improve the understanding of regional phenomena in a climate change context, in particular extreme weather events e.g., heat waves, storms, winds, floods, droughts, precipitation, Termonia et al. (2018) and Belušić et al. (2017) and their attribution to human activities (Stott et al. 2015; Luu et al. 2018; Philip et al. 2018; Kew et al. 2018).

- Cross cutting themes: e.g., water resources/hydrological cycle (Donnelly et al. 2017), energy-climate nexus (Jerez et al. 2015; Tobin et al. 2016; Tobin et al. 2018)

The strategic challenges confronting EURO-CORDEX are closely aligned with the goals of CORDEX mentioned above. Although progress on point (i) has been demonstrated, substantial gaps remain and EURO-CORDEX will need to address the following issues related to point (ii) over the coming years:

- Quality control: EURO-CORDEX certified processbased assessments, which seek to attribute model performance to emerging processes, e.g., conditions originating from the interaction of components of a complex system.

- Creation of climate information through

- stronger involvement of the statistics community and "big data" analytics strategies as well as stronger engagement with programs and bodies which focus on vulnerability, impacts, adaptation and climate services (VIACS) such as GEWEX (www.gewex.org), Copernicus Climate Change Service (C3S; https://climate. copernicus.eu) and Future Earth (www. futureearth.org).

- development of approaches to assess the credibility and robustness of multi-modelmulti-method ensemble projections, and to synthesize these into user-relevant narratives (Benestad et al. 2017a)

- Knowledge transfer and exchange with the GCM community, in particular by contributing to the WCRP 
Grand Challenges relevant for Europe and by quantifying the GCM limitations induced by simulating the climate at low resolution (Giorgi et al. 2016).

As the needs of researchers and policy makers become ever more focused on local to regional impacts and phenomena (including features such as urban environments, hydrology, vegetation, land use) so must EURO-CORDEX evolve.

This manuscript is meant to provide a brief history of EURO-CORDEX and its predecessors ("A brief history of EURO-CORDEX"), the evolution of the community and its current organization ("Organizational structure of EURO-CORDEX"), the EURO-CORDEX modelling framework ("EURO-CORDEX modelling framework"), its scientific advances to date ("Scientific advances") and what these advances mean for the future ("Key messages and outlook").

\section{A brief history of EURO-CORDEX}

EURO-CORDEX stems from the achievements of former EU projects on regional climate modelling such as PRUDENCE and ENSEMBLES (Christensen et al. 2007; van der Linden and Mitchell 2009). In launching the CORDEX initiative, WCRP recognized that in order to produce, maintain and continuously analyze large ensembles of regional climate simulations, a large, longlasting and coordinated community effort is needed. Therefore the EURO-CORDEX community was formed in order to sustain and provide a structure for these activities concentrated on the European domain. As such, EUROCORDEX has always been a voluntary, self-organized and dynamic community that can grow and evolve with the changing landscape of climate research, high-performance computing and user needs. Due to the fact that EUROCORDEX builds on the efforts of previous projects and incorporates their lessons, it is also a role model for other CORDEX communities who are engaging in this type of effort for the first time.

Being a voluntary effort without base funding (similar to the larger CORDEX initiative and other endeavors such as CMIP), EURO-CORDEX nevertheless leverages its activities to obtain national and European funding. It also relies heavily on the enthusiasm and engagement of the participating researchers and institutions. The EUROCORDEX consortium meets yearly in the Climate Service Center in Hamburg, Germany (GERICS). The number of registered participants from the 1st General Assembly (GA) in 2011 to the 8th GA in 2018 grew from 40 to 64, with representatives from 18 European countries (Table 1). At the first meeting, the foundation for the activities of the upcoming years has been laid, including the modelling protocol that forms the backbone of the EURO-CORDEX ensemble. Since then, yearly meetings have provided an opportunity for presenting and discussing the major EURO-CORDEX activities and outcomes, and to decide about future plans and strategies. The EUROCORDEX community also provided a strong contribution to the two International Conferences on Regional Climate - CORDEX (Brussels, November 2013 and Stockholm, May 2016). In preparation for the Brussels conference the EURO-CORDEX community produced a press release to announce the release of the EURO-CORDEX data (based on studies by Jacob et al. 2014 and Vautard et al. 2013) entitled "New, detailed climate projections for Europe reveal changes in extreme events and open the way for climate change impact studies." Further research activities were discussed including the analysis of low emission scenarios, including the $+1.5^{\circ} \mathrm{C}$ and $+2{ }^{\circ} \mathrm{C}$ global warming targets, which resulted in recent studies that use many EURO-CORDEX simulations to assess the impacts of these warming targets over Europe (Jacob et al. 2018; Kjellström et al. 2018; Teichmann et al. 2018). General assemblies are also an opportunity to reflect critically on the work performed and address emergent challenges.

EURO-CORDEX is conceived as both a dynamical and a statistical downscaling activity. Modelling groups focusing on dynamical downscaling are using the following regional climate modelling systems: ALADIN-Climate (Colin et al. 2010), CCLM (Böhm et al. 2006; Will et al. 2017; Rockel et al. 2008), HIRHAM (Christensen et al. 2007), RACMO (Van Meijgaard et al. 2012), RCA (Samuelsson et al. 2011), RegCM (Giorgi et al. 2012), REMO (Jacob et al, 2012, 2014), PROMES (Domínguez et al. 2010; Domínguez et al. 2013), WRF (Skamarock and Klemp 2008), and ALARO-0 (Giot et al. 2016; Termonia et al. 2018).

Modelling groups focusing on empirical statistical downscaling (ESD) employ a wide range of approaches (Benestad et al. 2017a; Maraun et al. 2015, 2018; Gutiérrez et al. 2018; Hertig et al. 2018; Soares et al. 2018; Widmann et al. 2019). The two approaches to downscaling are seen as complementary within the EURO-CORDEX community, each with its relative strengths.

\section{Organizational structure of EURO-CORDEX}

In order to evolve and adequately address emerging challenges, the EURO-CORDEX community has refined its structure during its existence. Initially, two coordinators were sufficient to manage the dynamically downscaled ensemble. However, new challenges meant that it was necessary to expand the number of coordinating members. 
Table 1 EURO-CORDEX General Assembly (GA) participation and milestones

\begin{tabular}{|c|c|c|c|c|}
\hline Date & General Assembly & Decisions/milestones & Participants & Countries \\
\hline $11 / 2011$ & First & $\begin{array}{l}\text { Organize modelling and evaluation activities; } \\
\text { create databases in ESGF format, experimental } \\
\text { design, requirements for simulations }\end{array}$ & 37 & 14 \\
\hline $01 / 2012$ & Second & $\begin{array}{l}\text { Collect observational datasets; application of } \\
\text { statistical downscaling techniques }\end{array}$ & 44 & 13 \\
\hline $10 / 2013$ & Third & $\begin{array}{l}\text { Preparation for the International CORDEX con- } \\
\text { ference } 2013\end{array}$ & 28 & 13 \\
\hline $03 / 2014$ & Fourth & $\begin{array}{l}\text { Enhance integration with impact modelling; focus } \\
\text { on science }\end{array}$ & 30 & 12 \\
\hline $01 / 2015$ & Fifth & $\begin{array}{l}\text { Encompass both statistical and dynamical down- } \\
\text { scaling methods; scientific focus on land use } \\
\text { change impacts }\end{array}$ & 47 & 13 \\
\hline $01 / 2016$ & Sixth & $\begin{array}{l}\text { New organizational structure; Prepare for } 2 \text { nd } \\
\text { EURO-CORDEX phase; FPS preparations }\end{array}$ & 49 & 16 \\
\hline $01 / 2017$ & Seventh & Launch of flagship pilot studies & 55 & 17 \\
\hline $01 / 2018$ & Eighth & Establish new research themes & 64 & 18 \\
\hline
\end{tabular}

The new structure, shown in Fig. 1, is an outcome of the 6th GA in 2016. There, the EURO-CORDEX community acknowledged that downscaling is achievable through different approaches, and that dynamical and statistical approaches are complementary to each other with different strengths and weaknesses. Both approaches are needed to address the challenges ahead. As a result, there are now two working groups devoted to specifically tackle issues related to dynamical and statistical downscaling, respectively, although they interact with each other.

Further, a third working group was formed explicitly focussing on Climate Information Distillation (CID). As discussed previously, this activity emerged as the scientific community acknowledged the challenges that users face when adopting climate data in decision-making contexts. The vast amounts of data produced from multi-model
Fig. 1 Organizational structure of EURO-CORDEX based on the decision in the 6th GA. Point of contacts (POCs) are shown for each of the EURO-CORDEX pillars

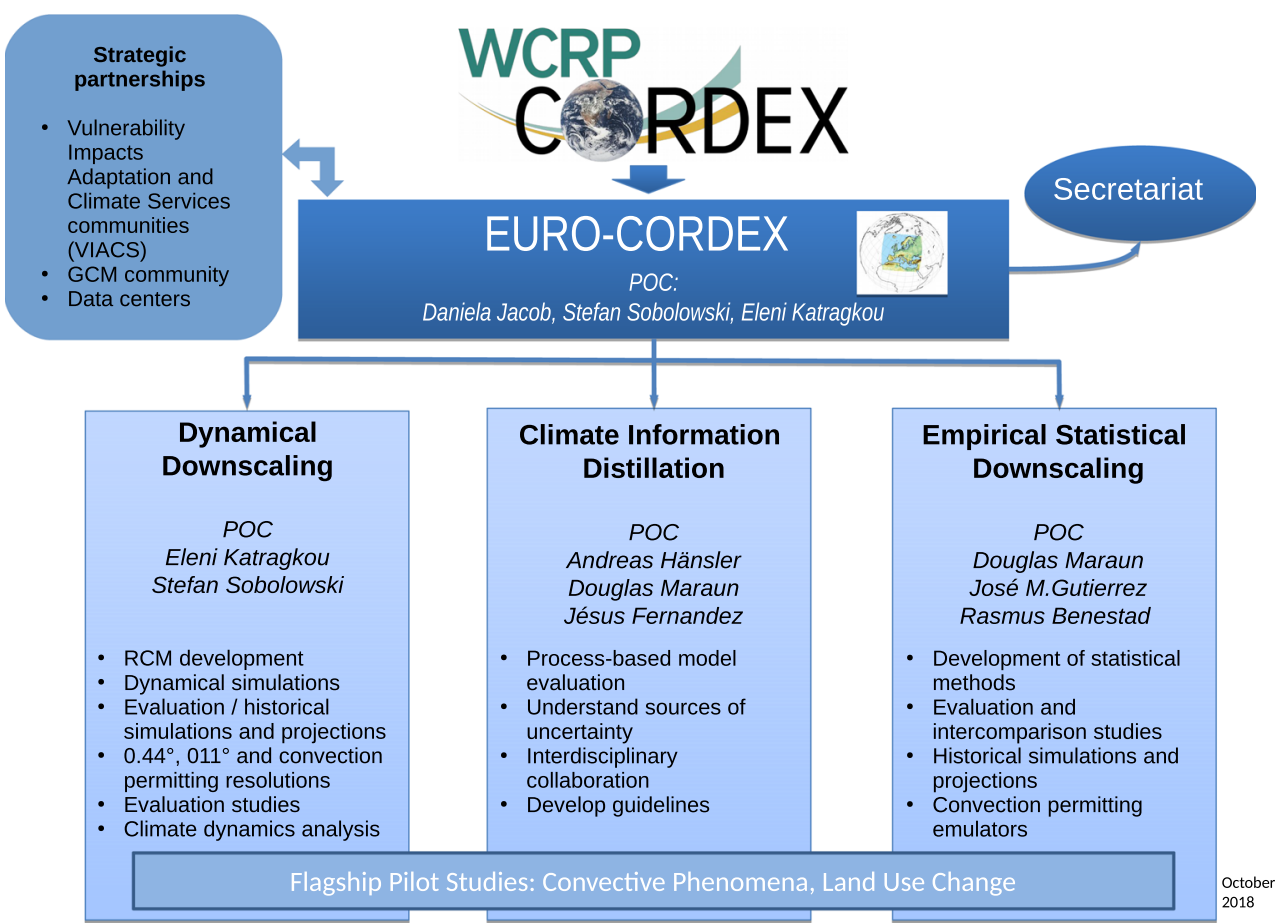


ensembles with different model combinations make stateof-the-art statistical methods necessary in order to make sense of all the data, however, the statistics community has not yet been widely engaged in the analysis of the data (Benestad et al. 2017b). This activity is seen as crucial to the effective integration and collaboration between EUROCORDEX and the VIACS/policy communities, as this is where the output of the scientific activity makes its way into decision-making. Deser et al. (2012) pointed out that GCMs produce pronounced chaotic variations on regional scales even over decades, and demonstrated that one model with slightly different initial conditions could produce a wide range of local scenarios. One important question therefore concerns the minimum size of a reliable ensemble that is not susceptible to random fluctuations and the law of small numbers (Benestad et al. 2017b). Given the multiplicity of messages, users may be inadequately prepared to incorporate state-of-the-art climate information or may make inappropriate decisions if messages from limited, nonrobust, unreliable subsets of data are adopted (Fernández et al. 2019). Currently, a group of scientists is forming to tackle the issue of CID, including dynamical and statistical downscaling researchers from EURO-CORDEX, but also global climate modelers, atmospheric dynamicists, climate service providers and philosophers. Initial teleconferences took place during spring of 2018 and additional activities are planned.

\section{EURO-CORDEX modelling framework}

In order to assure a high-quality and easy to handle ensemble of simulations, the EURO-CORDEX modelling strategy was implemented at the first GA. It consists of a controlled experiment setup containing a fixed simulation domain (Fig. 2), predefined horizontal grid spacings, an evaluation simulation for each model used within EUROCORDEX and a historical and climate change simulations, following the endorsed CORDEX protocol (Giorgi and Gutowski 2015). The following are the time periods covered by the simulations: Evaluation (ERA-Interim), 1989-2008; Control, 1951-2005; Scenarios, 2006-2100.

Within EURO-CORDEX, one domain with two resolutions is used for the RCM simulations: the EUR-44 domain at $0.44^{\circ}$ grid spacing, which is similar to what is used in the first phase of CORDEX experiments, and the EUR-11 domain at $0.11^{\circ}$ grid spacing. Therefore, together with an ensemble at the CORDEX standard resolution (at $0.44^{\circ}$ ), an ensemble of high-resolution regional climate simulations has been created (at $0.11^{\circ}$ ), aiming at better resolving
Fig. 2 EURO-CORDEX model domain at $0.11^{\circ}$ resolution

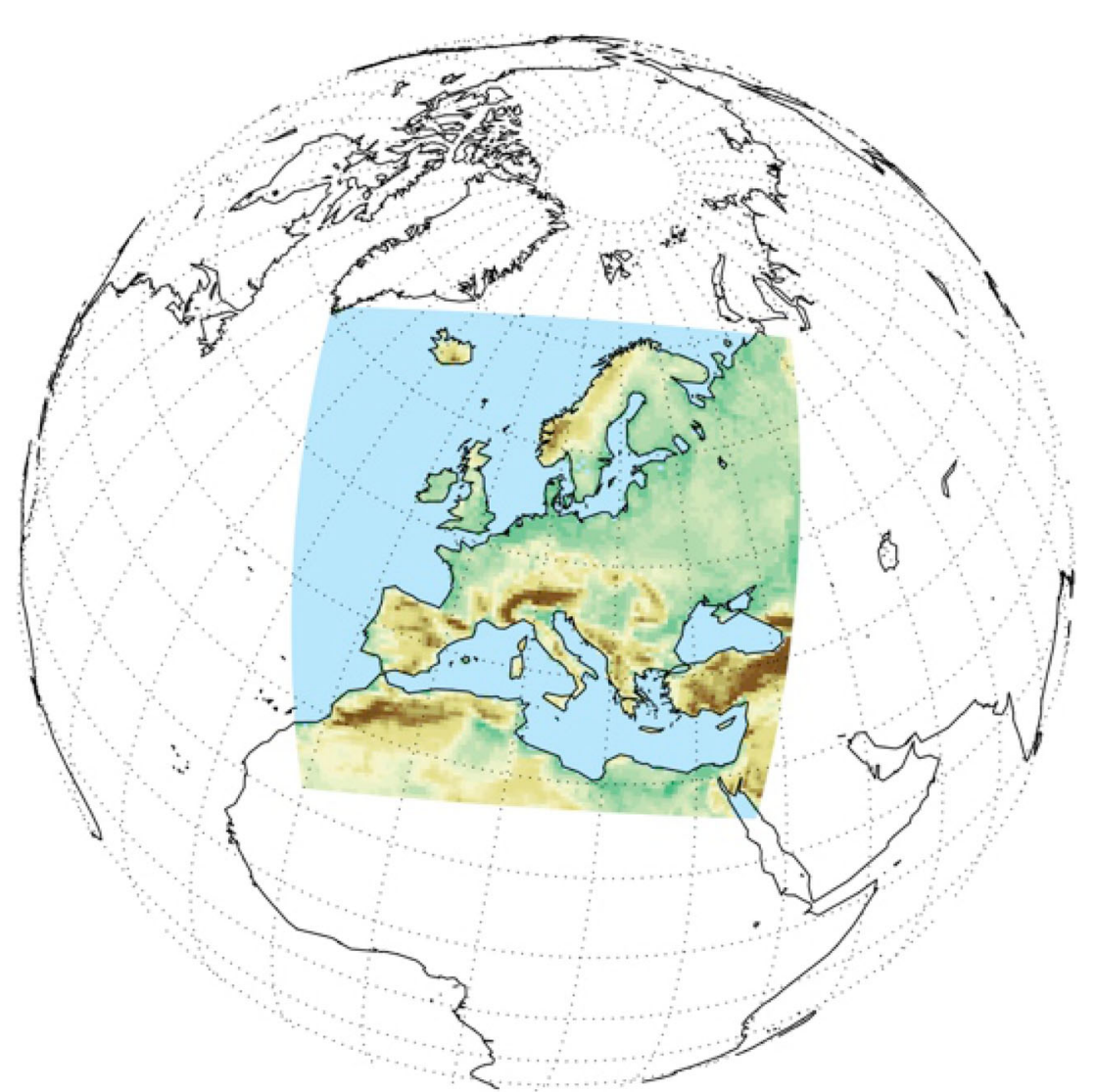


meteorological phenomena, including extreme events, over Europe. At both resolutions, three types of experiments are performed: reanalysis-driven evaluation runs designed to assess RCM capacity to properly simulate regional climate in a "perfect" boundary conditions setup, GCM-driven historical simulations, and GCM-driven climate projections designed to assess current and future climate change. GCM simulations are directly downscaled using RCMs (GCM to EUR-11) or via an intermediate step using a EUR-44 simulation which is then downscaled to EUR-11 (GCM to EUR-44 to EUR-11) (Fig. 3). Simulations are accessible via the ESGF data distribution facility at both a resolution of $0.44^{\circ}$, but also at a higher resolution of $0.11^{\circ}$ which is unique within the CORDEX framework.

All regional models used in EURO-CORDEX are evaluated using reanalysis-forced simulations (left hand side in Fig. 3) before running regional climate change projections driven by GCM forcing (right hand side in Fig. 3). Evaluation simulations are driven by "quasiobservational" data (ERA-Interim reanalysis; Dee et al. 2011) offering a robust basis for joint evaluation studies, atmospheric process analysis, comparison with previous projects, e.g., ENSEMBLES, and detailed evaluation against observational data. This provides some information about the performance of the individual RCMs over Europe, along with the presence of common systematic biases. Data are quality controlled before being uploaded to the ESGF repository, and best practices on the use of the regionally downscaled ensembles are provided (see https://euro-cordex.net). Furthermore, a joint errata service, accessible via https://euro-cordex.net, has been set in place in order to inform users on erroneous or equivocal simulation output.
In EURO-CORDEX, the choice of the driving GCM for the climate projection runs is largely up to each participating modelling group, given that it is a voluntary effort. This kind of approach can result in an ensemble of opportunity that might suffer from inconsistent climate change signals (Turco et al. 2013) or be biased towards a few preferred GCMs (Fernández et al. 2019). To avoid this, there has been a strong effort within EURO-CORDEX, and also from other initiatives, to analyze the driving GCMs, both regarding their performance (e.g., Cattiaux et al. 2013; McSweeney et al. 2014; Brands et al. 2013; Belda et al. 2015) and the spread of their mean seasonal temperature and precipitation changes (following the methods of Mendlik and Gobiet (2015) and McSweeney et al. (2014), or using a climate classification in Belda et al. (2016) or for their changes in weather regime frequency (Cattiaux et al. 2013). These analyses serve as support in the selection of forcing GCMs, in the sense of performance under current climate, but also in order to span the full spread of the GCM climate change signals over Europe. So while EURO-CORDEX does not explicitly follow a systematic experimental design as proposed by McSweeney et al. (2014) it does incorporate selection criteria. Further, most of the GCMs used in EUROCORDEX are among those listed as well performing by McSweeney et al. (2014) for Europe. Nevertheless, the GCM-RCM simulation matrix is sparse. Therefore, national projects such as ReKlies-DE (http://reklies.hlnug.de) and international activities such as the EU-funded Copernicus Climate Change Services (C3S; https://climate.copernicus. eu) are supporting EURO-CORDEX in filling this GCMRCM-simulation matrix in a coordinated effort. There have also been $\mathrm{C} 3 \mathrm{~S}$ projects for the evaluation and quality control (EQC) of climate model data (https://climatedatasite.net/).
Fig. 3 Schematic description of the EURO-CORDEX experiment protocol. For further details refer to the text

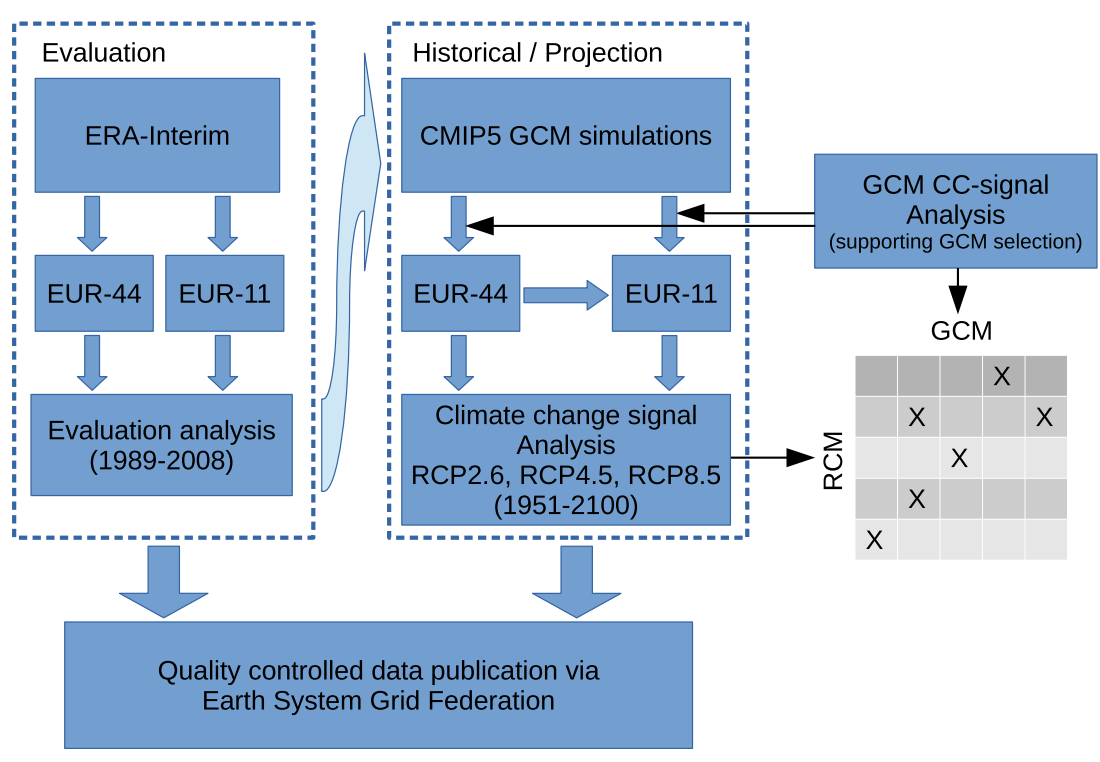




\section{Scientific advances}

Early on, EURO-CORDEX committed itself to make data available through open access services such as the ESGF (https://esg-dn1.nsc.liu.se/projects/esgf-liu/) and climate impact web portals (https://climate4impact.eu). The availability of a large multi-model ensemble in a coordinated framework (evaluation, historical and future simulations), on different spatial resolutions and for a range of Representative Concentration Pathways (RCPs) is a significant contribution to the climate science community. It has provided the researchers with a solid basis from which to investigate present and future European climate, and assess uncertainty on continental to regional scales.

At the eighth GA (January 2018), a renewed commitment was made towards community-driven research on highimpact topics with a focus on contributing to the next IPCC assessment report. These topics include the following: urban scale issues, added value, impacts (with a focus on extremes), emergent constraints, interactions/feedbacks, and dynamics/thermodynamics. Another outcome of the GA was the establishment of a EURO-CORDEX errata page where issues noted by modelling teams and users are gathered, described and addressed in an accessible and transparent manner. A third decision was to update and improve model/experiment documentation. This will include synchronizing EURO-CORDEX documentation with ongoing $\mathrm{C} 3 \mathrm{~S}$-funded projects.

\section{Evaluation studies and projections of future European climate}

The EURO-CORDEX evaluation simulations have served as the data-pool for a series of investigations concerning current European climate and the ability of regional models to accurately represent its state, its range of uncertainty and systematic model biases on a continental (e.g., Kotlarski et al. 2014; Katragkou et al. 2015; García-Díez et al. 2015) or regional level (e.g., Belušić et al. 2017; Dyrrdal et al. 2017). These simulations also provide a basis for assessing the added value, or lack thereof, of regional climate models. One way to look at downscaling is that information is added, with an improved physical understanding (i.e., though explicit inclusion of more processes/phenomena) and more geographical detail. At the same time, the downscaling can also introduce new errors and biases (e.g., additional uncertainties, mismatches between GCM and RCM in terms of parameterizations). The case for added value is where the addition of information dominates over the addition of uncertainty. However, the question of added value also depends on how the results are being used. For example, there is recent work that shows that the biases and uncertainty in GCM-RCM chains are not additive, i.e., uncertainty does not increase with each downscaling step and that RCMs in the EURO-CORDEX framework improve on the GCMs even at larger scales (Sørland et al. 2018).

The added value of higher resolution simulations was also addressed, both directly and indirectly, in a number of studies including dynamical downscaling (Warrach-Sagi et al. 2013; Torma et al. 2015; Casanueva et al. 2016b; Coppola et al. 2018a; Prein and Gobiet 2016; Ivanov et al. 2017; Soares and Cardoso 2017; Fantini et al. 2018; Sørland et al. 2018) and statistical methods (Casanueva et al. 2016a; Soares et al. 2018). Joint evaluation studies also focused on extreme climate events, such as heat waves (Vautard et al. 2013; Lhotka et al. 2017) and extreme precipitation (Fantini et al. 2018), medicanes (Gaertner et al. 2018) or physical process analysis, such as land-atmosphere interactions (e.g., Davin et al. 2016; Knist et al. 2017) and coastal circulations (Cardoso et al. 2016). Many of these examples point to an added value of regional downscaling by including processes or phenomena that are missing from coarser resolution models (e.g., Prein et al. 2015; Cardoso et al. 2016; Davin et al. 2016; Knist et al. 2017; Fantini et al. 2018). In other cases, such as in studies focusing on mean climate conditions involving spatially or temporally averaged fields (e.g., Kotlarski et al. 2014; Casanueva et al. 2016b) and/or phenomena with strong links to large scale circulation (Vautard et al. 2013), the added value is less apparent. However, a comprehensive assessment of added value in CORDEX RCM simulations is still lacking.

The historical and projection simulation datasets are the basis for the investigation of current and future European climate, including investigation of uncertainty stemming from model variability and projection scenarios. Jacob et al. (2014) used the higher resolution $\left(0.11^{\circ}\right)$ EUROCORDEX simulations to show the overall spatial patterns for temperature and precipitation changes and related indices are similar to those of ENSEMBLES, with a slightly stronger mean precipitation increase over most of Europe and a reduced northwards shift of Mediterranean drying evolution. Bador et al. (2017) investigated the evolution of the record temperatures showing that maximum temperatures above $50{ }^{\circ} \mathrm{C}$ can occur at the end of the 21 st century under the RCP8.5 scenario. Tramblay and Somot (2018) used the EUR-11 EURO-CORDEX ensemble to investigate the intensity and the time of emergence of the response of Mediterranean extreme precipitation to climate change. They showed a robust north-south pattern with increase (resp. decrease) in the North (resp. South) of the basin. Related to these projected shifts are projected changes in extreme dry spells, which may increase in duration and extent over the Mediterranean basin (Raymond et al. 2019). Jerez et al. (2015) and 
Bartók et al. (2017) compared changes in solar radiation projected by global and regional EURO-CORDEX climate models and reported a discrepancy between the results in the GCM/RCM ensembles, namely increasing/decreasing trends for the period 2006-2100 over Europe under RCP8.5. Tobin et al. (2016) analyzed changes in surface wind speed and wind power in Europe, using EUROCORDEX simulations, and Tobin et al. (2018) assessed general changes in electricity production in Europe. Others have also investigated renewable energy projections and note a more challenging environment for wind energy management in the future (Moemken et al. 2018). Several other studies used the EURO-CORDEX projections to focus on regional/national level (e.g., Smiatek et al. 2016; Rulfová et al. 2016; Ouzeau et al. 2016; Soares and Cardoso 2017; Hosseinzadehtalaei et al. 2018; Bador et al. 2017; Fernández et al. 2019; Huebener et al. 2017; Kjellström et al. 2016; Rajczak and Schär 2017; Púčik et al. 2017; Frei et al. 2018; Termonia et al. 2018; Prein and Gobiet 2016; Stepanek et al. 2016; Cardoso et al. 2018) others applied statistical downscaling methods, to further downscale the regional climate information (e.g., Dosio 2016; Mezghani et al. 2017) while others, after adopting bias adjustment techniques, use EURO-CORDEX data for local applications (Reder et al. 2018; Croce et al. 2018).

EURO-CORDEX simulations were recently used to assess the human influence in recent individual extreme events, together with other projection ensembles, a type of analysis which is called "event attribution" (Stott et al. 2015). EURO-CORDEX does not include pre-industrial simulations but changes between an earlier historical period (e.g., 1971-2000) and a "current climate" period (e.g., 2001-2030) allows to estimate a lower bound of human influence on regional climate events. In this way, Kew et al. (2018) showed that heat waves such as the 2017 summer "Lucifer" heat wave in Southern Europe had a probability that had strongly increased due to human influence. Other cases were studied using EURO-CORDEX, such as the extreme precipitations over the Cévennes mountains range (Luu et al. 2018), the European drought of Summer 2015 in Central Europe (Hauser et al. 2017) the extreme wind stagnation of December 2016 (Vautard et al. 2018), and the winter wind storms of January 2018 (Vautard et al. 2019). The added value of high resolution was demonstrated in particular for the Mediterranean heavy precipitations. As a final example, Giorgi et al. (2016) showed the added value of high-resolution RCMs in the projection of summer precipitation changes over high mountainous areas (e.g., the Alps). An overview of EURO-CORDEX publications can be found in the EURO-CORDEX publication web pages (http://euro-cordex.net).

\section{Flagship pilot studies}

The flagship pilot studies (FPS) initiative was established by the CORDEX Scientific Advisory Team as an additional activity to the core work of CORDEX, analogous to the MIPs of Coupled Model Intercomparison Project (CMIP) (Gutowski et al. 2016). These are "bottom up" initiatives and benefit the larger CORDEX/Working Group on Regional Climate (WGRC, https://www.wcrp-climate. org/regional-climate) bodies through linking to the wider climate research community, such as the newly established MIPs and other WCRP core projects. The EURO-CORDEX community submitted two successful FPS applications, one on the climatic impacts of land cover changes and one jointly with the Med-CORDEX community (Ruti et al. 2016; Somot et al. 2018) on convective phenomena through the use of very high-resolution convection-permitting regional climate models (CPRCMs). These computationally intensive projects started up in 2017 and just recently begun to produce results.

\section{FPS I Land Use and Climate Across Scales}

Land Use and Climate Across Scales (LUCAS) is a new initiative on coordinated regional climate experiments for Europe including land use change forcing (https://www. hzg.de/ms/cordex_fps_lucas/). It was initiated jointly by EURO-CORDEX and LUCID (Land-Use and Climate, IDentification of robust impacts, http://www.lucidproject. org.au). Land use change (including land cover and/or land management changes) is an important anthropogenic forcing on climate, and its direct biophysical effect on temperature can locally or regionally be of the same order of magnitude as the effect from global greenhouse gas forcing, but there are still uncertainties in magnitude and sign of many land-induced changes (de Noblet-Ducoudré et al. 2012; Lejeune et al. 2017; Perugini et al. 2017; Cherubini et al. 2018). Even more important for impact studies, many numerical experiments have highlighted the strong impact land uses may have on extreme events (e.g., Pitman et al. 2012; Davin et al. 2014; Thiery et al. 2017; Lejeune et al. 2018; Berckmans et al. 2019).

The LUCAS initiative is complementary to the Land Use Model Intercomparison Project (Lawrence et al. 2016) in that LUMIP focuses on the global scale, while LUCAS investigates regional impacts, using higher resolution, closer to the scale at which the biogeophysical effect of LUC has the strongest impacts. Up till now, this human forcing is not accounted for in RCM climate change projections. RCMs have been applied individually for investigating impacts of land use changes on regional climate in different world 
regions (e.g., see reviews of Pielke et al. 2011; Lawrence and Vandecar 2015; Santanello et al. 2018). Most results are model specific and therefore do not allow one to derive robust conclusions. In LUCAS, for the first time an ensemble of RCMs will be used in coordinated land use change (LUC) experiments, focusing on anthropogenic land cover conversions and potentially on land management practices during its later phase. The LUCAS modelling framework is visualized in Fig. 4.

The overall objectives of LUCAS are (i) to identify robust biophysical impacts of land use change on climate across regional-to-local spatial scales and at various time scales, from extreme events to multi-decadal trends, and (ii) to provide robust information in support of effective land use practices and also help guide decisions on land management from unintended consequences. The questions to be addressed are:
- How sensitive are regional climate models to land use change and how is this interrelated to landatmosphere coupling in different regions among the suite of models?

- How large is the relative contribution of land use change compared with other forcings in the detection of past and potential future climate trends?

- How do land use practices modulate climate variability? Can local land use change modulate extreme climate conditions?

- What is the effect of spatial resolution on the magnitude and robustness of land use change-induced climate changes?

- What errors do we make on the downscaled climate change if we ignore land use change? This is especially important for subsequent impact studies.

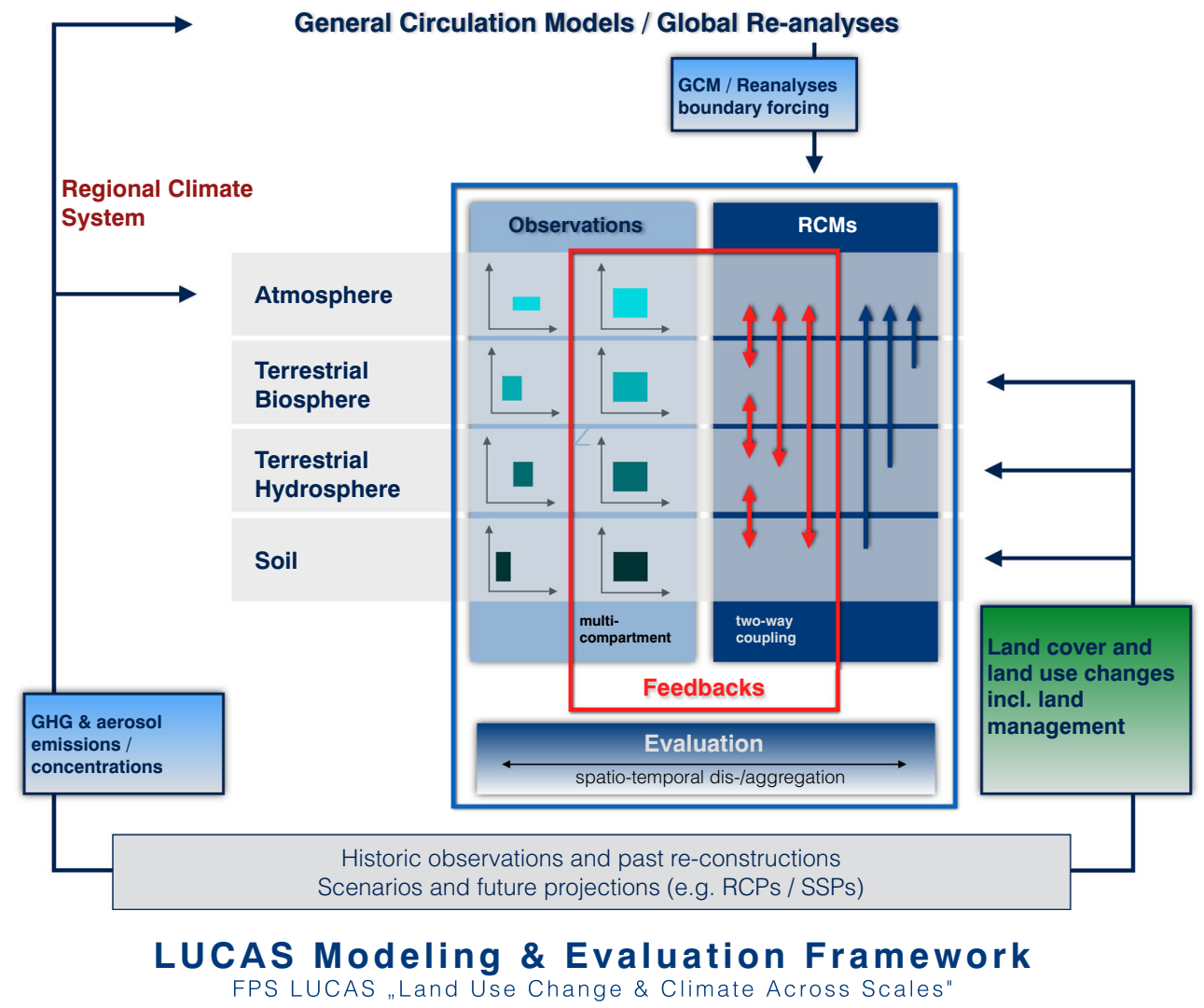

Fig. 4 LUCAS modelling framework. Land use and climate change experiments are performed with several RCMs. They represent processes in atmosphere, terrestrial biosphere, hydrosphere and pedosphere. RCMs which apply a two-way coupling between the atmosphere and the terrestrial components, enable the investigation of land-atmosphere feedbacks. The evaluation experiments are driven by reanalysis data and compared with observational data. Multicompartment observational data on consistent temporal and spatial scales enable the evaluation of land-atmosphere feedbacks. The climate change experiments are driven by GCMs. Greenhouse gas (GHG) and aerosol concentrations are prescribed to the model simulations according to observed past concentrations for historical time periods, and according to different RCPs for climate change projections. Land cover and land use changes are implemented into the RCMs according to observed past re-constructions for historical time periods, and according to different Shared Socio-Economic Pathways (SSPs), which are linked to certain RCPs, respectively. Additional land use change experiments are designed, for which specific land use forcings are developed and implemented 
It is clear that the outcome of these simulations will be limited as long as the representation of surface fluxes, boundary layer turbulence, and cloud microphysics cannot be verified and improved. Therefore, these modelling efforts will be accompanied by field experiments on land-atmosphere feedback (Wulfmeyer et al. 2018), which are currently being evaluated or prepared, e.g., at the TERENO sites (Bogena 2016) and the new Land-Atmosphere Feedback Observatory (LAFO; see https://lafo.uni-hohenheim.de).

Cropland management as well as human water use by water extraction and irrigation is an emerging topic and has the potential to either enhance or dampen temperature extremes (Becker et al. 2013; Davin et al. 2014; Thiery et al. 2017; Keune et al. 2018). Also, the collaboration between the FPS LUCAS on land-atmosphere feedback, the WRCP LoCo community (Santanello et al. 2018) and experiments on land-atmosphere feedback (Wulfmeyer et al. 2018) including groundwater dynamics (Keune et al. 2016) should be intensified.

\section{FPS II convective phenomena at high resolution over Europe and the Mediterranean}

The second FPS mobilizes the EURO- and MED-CORDEX communities and aims to bring fresh perspectives and expertise on issues surrounding convective phenomena. Present and future convective extremes and their processes are under investigation with convection-permitting regional climate models (CPRCMs), at resolutions finer than $3 \mathrm{~km}$, over selected sub-regions of Europe and the Mediterranean (Fig. 5). Advanced statistical techniques will also be employed in parallel to evaluate the performance

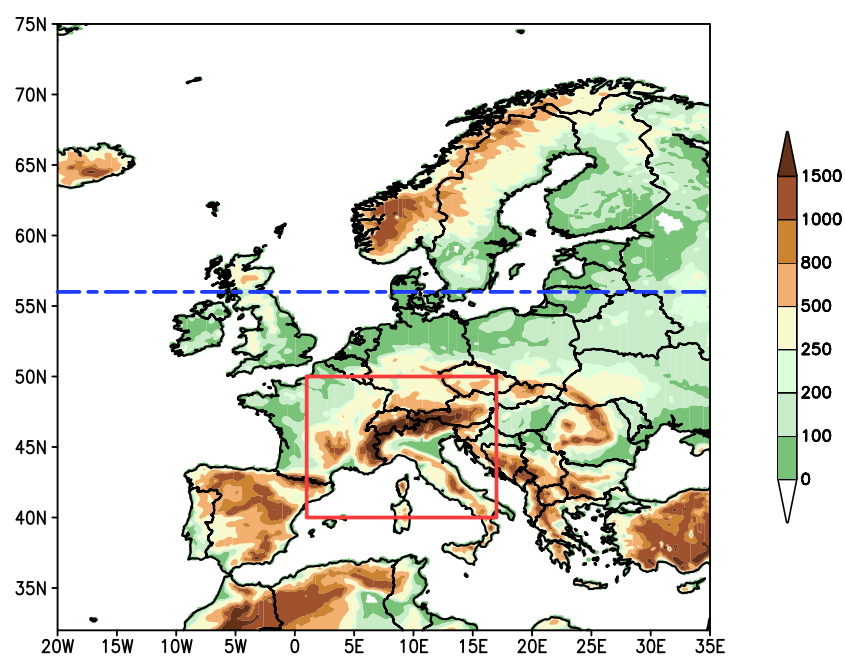

Fig. 5 Mandatory domain for the FPS on convective phenomena (red box). The dashed blue line corresponds to the northern boundary of the Med-CORDEX domain of dynamical models, to potentially serve as emulators of convective extremes, and to detect and attribute their changes. These so-called emulators use empirical relationships between large scales features and local phenomena such as precipitation in ways similar to statistical downscaling but then add additional detail to obtain, e.g., sub-daily rainfall (Mezghani et al. 2019). The FPS aims to extend these to also include information from the dynamical downscaling. The added value of CPRCMs is well established now, especially for mesoscale convective systems, rainfall extremes, diurnal cycles, regional snow cover, etc. (see Ban et al. 2014; Prein et al. 2015, 2017a; Berthou et al. 2018; Sørland et al. 2018; Lüthi et al. 2019; Scaff et al. 2019). What has not been done as yet, is to explore these advances in an ensemble framework, which will allow us to better estimate uncertainty, quantify robustness and elucidate key driving processes. The added value of explicitly simulating deep convection will be rigorously evaluated with respect to both coarser resolution simulations up to GCM scales and VIACS applications. The CPRCM simulations will also serve as references and help developing convection parameterizations in standard RCMs and GCMs. The availability of observational datasets at very high resolutions in both space and time allows unprecedented evaluation opportunities (e.g., Lussana et al. 2018; Hiebl and Frei 2016, 2018; Frei 2014).

This FPS has three main scientific questions with many attendant sub-topics and questions:

- How do convective events and associated damaging phenomena (heavy precipitation, wind storms, flashfloods) respond to changing climate conditions in different climatic regions of Europe?

- Does an improved representation of convective processes and precipitation at convection-permitting scales lead to downscaled as well as upscaled added value?

- To what extent do lateral boundaries affect convectionpermitting model (CPM) performance and how can corresponding errors be reduced?

- Is it possible to complement costly convectionpermitting experiments with physically defensible statistical downscaling approaches such as "convection emulators" that mimic CPMs and are fed by output from conventional-scale climate models?

Convective extreme events are a priority under the WCRP Grand Challenge on weather and climate extremes, because they carry both society-relevant and scientific challenges that can be tackled in the coming years. Further, "coordinated modelling programs are crucially needed to advance parameterizations of unresolved physics and to assess the full potential of CPMs" (Prein et al. 2015). The project involves over 20 modelling teams and consists 
of three modelling steps: test cases, evaluation runs and scenario runs. A presentation of the project and preliminary results appear in Coppola et al. (2018b). Figure 6 shows results from a test case over Switzerland and highlights the ensemble performance in reproducing an extreme Foehn event in November of 2014. The ensemble mean spatial pattern correlations for this event were over 0.90. However, the ensemble exhibits much larger spread for events that are more weakly forced by the synoptic background state and have strong orographic and/or land-ocean interactions. Simulations over climate scales (10 years time slices) under present and future conditions are ongoing. A small ensemble has recently been completed (fall 2019) and a number of investigations are underway with results expected in late 2019/early 2020.

\section{Key messages and outlook}

The scientific challenges EURO-CORDEX faces will require broad community-based research. Given the fragmented nature of funding for EURO-CORDEX and CORDEX generally, there is a need for funding that targets these types of research initiatives. Only in this way will significant improvements in fundamental understanding emerge. A non-exhaustive list of directed research
Fig. 6 Time series of 12 hourly accumulated precipitation for a Foehn event over southern Switzerland (black line/dots, in $\mathrm{mm}$ on the right hand $\mathrm{y}$-axis) during the event and temporal evolution of the spatial correlation (lefthand y-axis) of the accumulated 12 hourly precipitation between the simulations and observations, panel a. Number of models with a correlation greater than 0.5 for WL simulation (in blue) and CM simulation (in red). Time series of the accumulated precipitation averaged over the region covered by the observations for each model (colored lines) versus observations (black line), panel b. Time series of accumulated hourly precipitation for the ensemble means of the WL and $\mathrm{CM}$ simulations versus observations (blue, red and black lines, respectively), panel c (Reproduced from Coppola et al. (2018b))
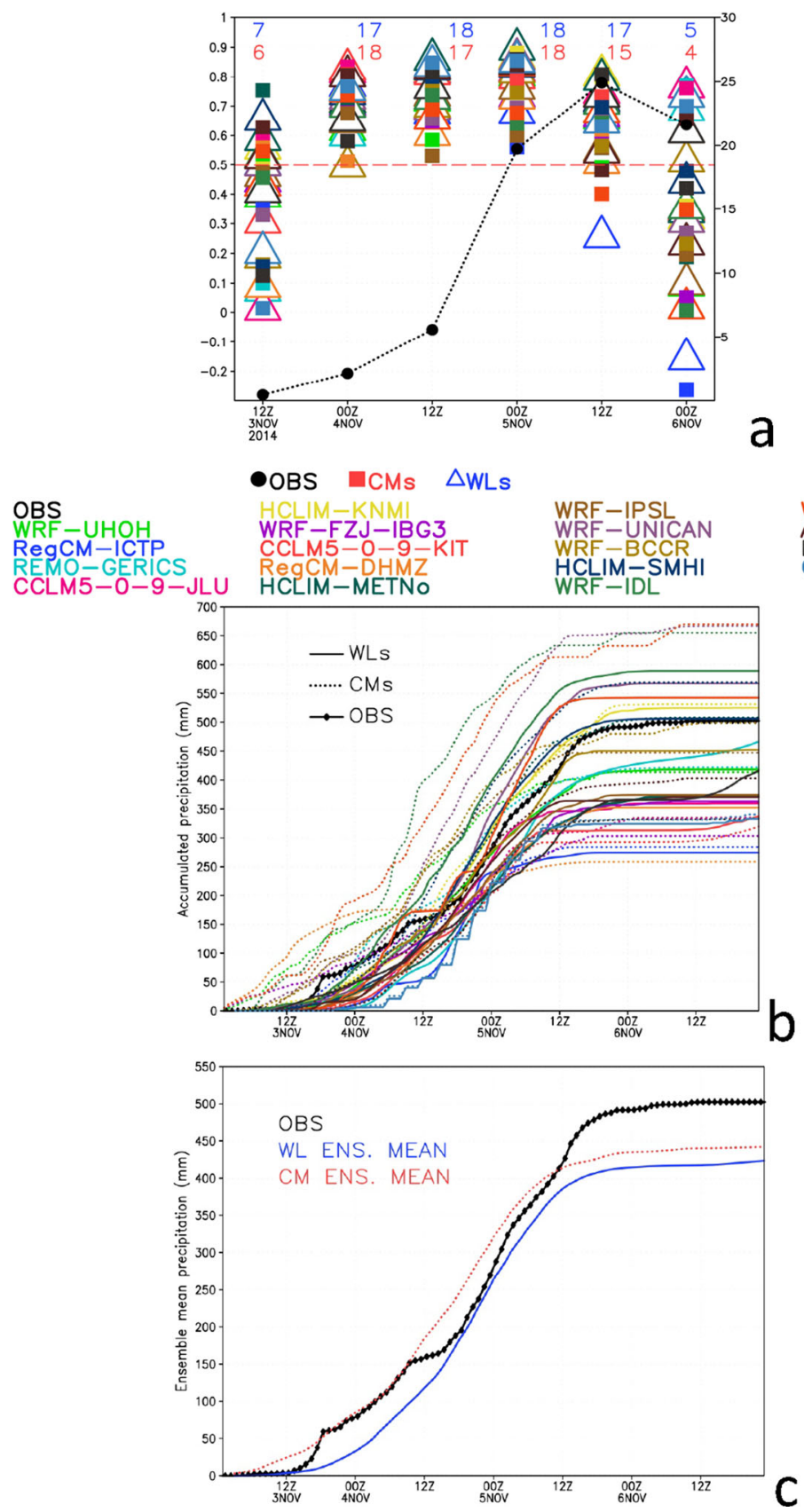
recommendations are presented below. These are followed by more detailed descriptions of key messages and the future outlook from the EURO-CORDEX community, which include not only research but also necessary expansion of the community to include additional perspectives.

- Research towards a more comprehensive and improved understanding of regional climate processes and their drivers, in particular with respect to extremes and place these within the context of the Sustainable Development Goals and WCRP Grand Challenges.

- Research towards transient continental-scale ensemble kilometer scale modelling (i.e., convection permitting) has the potential to substantially reduce uncertainties in future climate projections and enhance our understanding of high-impact weather events under climate change; the community is moving in this direction but such initiatives require significant and sustained investment in personnel and resources

- Research support for the interdisciplinary community that will be needed to further develop Regional Earth system models that are able to better simulate the human impact on local and regional climate (e.g., vegetation feedbacks, hydrology and water resources, irrigation for agricultural production, urban climate, regional sea-level rise, storm surge modelling, coupled glacier modelling)

- Research that explicitly links observations to model development and improvement through collaborative community efforts that focus on regional and local process studies that make use of, e.g., field campaign data to improve the representation of processes and feedbacks in regional models.

\section{Linking with climate services}

In addition to generating a unique dataset to address many scientific issues pertaining to climate downscaling, the first phase of EURO-CORDEX has already had a tremendous impact on the provision of regional climate services. For example, several "official" national climate scenarios (examples include France (http://www.drias-climat.fr), Switzerland (www.ch2018.ch), Austria, Norway (https:// klimaservicesenter.no), Spain (http://escenarios.adaptecca. es) and Belgium (http://www.euro-cordex.be) for national climate change adaptation strategies are nowadays based on EURO-CORDEX. In addition, EURO-CORDEX will be at the heart of the coming C3S European climate service for future projections (e.g., the Copernicus Climate Change Service project C3S34b, PRINCIPLES, https:// climate.copernicus.eu). It has also been used in proof-ofconcept European climate services, for instance to help the energy sector facing climate change impacts and climate variability in developing renewable energies, or water, such as in the C3S CLIM4ENERGY and SWICCA projects (https://climate.copernicus.eu). Operational implementation is currently underway.

Despite the scientific progress and overall success of the EURO-CORDEX initiative, there are a number of challenges confronting it. These challenges are of both scientific and strategic nature. For example, simply generating and disseminating downscaled regional climate projections in the absence of good experimental design and without proper context, guidance and tailoring, will, at best, not serve user communities' needs optimally and, at worst, potentially lead to misleading strategies (Dilling and Berggren 2014). Avoiding such pitfalls will require both scientific advances on uncertainty quantification and verification metrics needed to produce robust and reliable projections, as well as strategic partnerships with outside collaborators in the VIACS communities. EUROCORDEX is directly addressing these challenges through the establishment of strategic partnerships (e.g., with the CMIP6-endorsed VIACS advisory board (Ruane et al. 2016) and a dedicated effort on CID (Fig. 1).

In the second phase of EURO-CORDEX, the ensemble of EUR-44 and EUR-11 simulations will be extended to serve as a robust basis for further studies and VIACS applications. Additional EURO-CORDEX objectives are to foster the creation of climate information including the interface to users and to integrate empirical statistical downscaling. The new structure of EURO-CORDEX (see Fig. 1) reflects these aims and gives us a good basis for future cooperation and collaborations with the broader community of climate change, sustainability and social transformations researchers. It is an ambitious and exciting platform but one that is timely and has a proven and dedicated community of practice built to support it.

\section{Integrating statistical methods}

As noted previously, the volume of data produced in the EURO-CORDEX downscaling activities requires advanced statistical techniques for robust analyses (Benestad et al. 2017a, b). Better integration of these techniques and collaboration with external experts is a key strategic aim for EURO-CORDEX. Steps have already been taken with participation of EURO-CORDEX teams in the EU COST Action ES1102 "VALUE" (Maraun et al. 2015), where statistical downscaling groups organized themselves to systematically investigate statistical downscaling and bias correction methods. In a first experiment, VALUE investigated the downscaling skill of some 50 statistical methods for present climate, when driven with reanalysis-based predictors. These results have recently been published in a special issue (Maraun et al. 2017, 2018; Gutiérrez et al. 2018; 
Hertig et al. 2018; Soares et al. 2018). These types of activities have been integrated into the ESD pillar into EURO-CORDEX (Fig. 1), and a new call for the next experiment will be issued shortly. This experiment will investigate the overall skill of statistically downscaled GCMs in present climate and the plausibility and uncertainties of future projections based on statistical downscaling.

\section{Receiving support from computer science}

The fields of climate science and climate change impacts heavily rely on computationally-intensive simulations and data centers should be aware of the wealth of data that is to come from the EURO-CORDEX community due to increasing ensemble sizes and heading towards convection-permitting resolutions. For instance, the effort in the setup and performance of CPM simulations was exemplified in latitude-belt runs by Schwitalla et al. (2017) or European, CPM simulations by Leutwyler et al. (2016) and on global scales by Heinzeller et al. (2016). On the other hand the climate modelling community, enabled by ever increasing high-performance computing resources, is facing large challenges related to new, emerging computing paradigms using, e.g., new microarchitectures such as GPUs (Lawrence et al. 2018) and finding more efficient ways to handle and store the massive amounts of data produced by CPM simulations. Additionally, there will be even more requests from VIACS communities for this data and online processing services to reduce the data volume on the server side. VIACS will have to bring together the large amount of high-resolution climate data and the requests of their customers for local climate information. They are challenged by the need of quick answers on the one hand and the desire to deliver high-quality well thought out and crafted products on the other. To address this issue targeted research and development to simplify and democratize data access and analysis and improve guidance for end-users in an era of data volume explosion will be needed. Here, a closer collaboration with the EURO-CORDEX community will help to address the challenges and fulfill mutual requirements.

\section{Fostering cooperation with WCRP activities}

The regional activities in WCRP are receiving increased visibility at present, and it is incumbent upon all involved to look for synergies across these activities. EURO-CORDEX, and CORDEX more generally, has a critical role to play in realizing WCRP's new scientfic objectives, in particular objective 4 "Bridging science and society" (WCRP Joint Scientific Committee (JSC) 2019). The EURO-CORDEX community itself is also challenged by the WCRP and CORDEX-specific grand scientific challenges. Some of them can be addressed together with other communities, such as VIACS or the larger climate science community including CMIP6. Here, closer and more active interaction is essential. Besides the scientific challenges, it is also necessary to support VIACS communities by providing well designed, large ensembles of climate simulations in a welldocumented and usable way. As a promising development, a robust community has formed around convectionpermitting modelling and two successful WCRP-GEWEX sponsored workshops, with strong participation from the EURO-CORDEX community, have been held in Boulder, Colorado. While advances are coming quickly, there are a number of challenges for this community to address (Prein et al. 2017b). EURO-CORDEX and its affiliated Flagship Pilot Studies are right at the forefront of this effort.

\section{Collaboration with the GCM community}

Finally, there is a tremendous strategic opportunity for EURO-CORDEX to pursue synergies with climate research activities mainly focused on GCM modelling through the establishment of CORDEX as a diagnostic MIP within the CMIP6 framework. This is also a non-trivial task, since institutional, disciplinary and philosophical barriers often remain between the two communities. However, increasing collaboration is very important, as CPMs are approaching the global scale and can be operated without lateral boundaries (e.g., Schwitalla et al. 2017). There exist a number of opportunities to evaluate upscaled added value, investigate emergent constraints on climate change at regional scales, provide feedback into GCMs to improve parameterizations, and for collaboration with higher resolution, convection-permitting GCMs.

Acknowledgments We acknowledge all participating institutions for their voluntary effort and contribution to EURO-CORDEX. We also thank the developers and maintainers of the ESGF-nodes who make it possible to store and distribute EURO-CORDEX data. S.S. acknowledges the support of NOTUR/NORSTORE projects NN9280K/NS9001K and the Research Council of Norway and its basic institute support of the strategic project on Climate Services. E.K. acknowledges the support of the Greek Research \& Technology Network (GRNET) for provision of technical support and facilities (HPC-ARIS). L.S. and I.G. acknowledge the support of Croatian Science Foundation project CARE (2831) and Ministry of Environment and Energy project TF/HR/P3-M1-O1-0101 (www. prilagodba-klimi.hr). J. F. acknowledges support from the Spanish R+D Programme through grant INSIGNIA (CGL2016-79210-R), cofunded by ERDF/FEDER, and the Altamira Supercomputer at Instituto de Física de Cantabria (IFCA-CSIC), member of the Spanish Supercomputing Network. P.T. acknowledges support from the Belgian Science Policy (BELSPO) within the CORDEX.be (BR/143/A2) project, and the VSC (Flemish Supercomputer Center), funded by the Research Foundation - Flanders (FWO) and the Flemish Government - department EWI.M.A.G. acknowledges support from the Spanish R+D Programme through grants CGL2013-47261-R and CGL201789583-R, co-funded by the European Regional Development Fund. RF acknowledges support provided by ICHEC (Irish Centre for High 
End Computing) and the Irish Environmental Protection Agency. K.G. and S.K. gratefully acknowledge the computing time granted through JARA-HPC on the supercomputers JUROPA and JURECA at Forschungszentrum Jülich. M.B. and T.H. acknowledge support by The Ministry of Education, Youth and Sports from the Large Infrastructures for Research, Experimental Development and Innovations project "IT4Innovations National Supercomputing Center LM2015070" and the INTER-EXCELLENCE program LTT17007, and support by Charles University from the PROGRES Q16 program. We acknowledge the approval and support of the two Flagship Pilot Studies (the FPS on Convective phenomena at high resolution over Europe and the Mediterranean and the FPS on Land Use and Climate Across Scales) by WRCP CORDEX. We thank Merja Tölle for providing simulation CCLM5-0-9-JLU as contribution to the CORDEX-FPS "Convective phenomena at high resolution over Europe and the Mediterranean".

D. M., M.P., and H.T. gratefully acknowledge the support received via the projects HighEnd:Extremes, SPIRIT, and reclip:convex, funded by the Austrian Climate Research Programme (ACRP) of the Klima- und Energiefonds (nos. B368608, B960272, and B769999, respectively), as well as the Jülich Supercomputing Centre (JSC) for compute time on JURECA through the grant JJSC39 and the Vienna Scientific Cluster (VSC) through the grants 70992 and 71193.

Funding Information Open Access funding provided by Projekt DEAL

\section{Compliance with ethical standards}

Conflict of interest The authors declare that they have no conflict of interest.

Open Access This article is licensed under a Creative Commons Attribution 4.0 International License, which permits use, sharing, adaptation, distribution and reproduction in any medium or format, as long as you give appropriate credit to the original author(s) and the source, provide a link to the Creative Commons licence, and indicate if changes were made. The images or other third party material in this article are included in the article's Creative Commons licence, unless indicated otherwise in a credit line to the material. If material is not included in the article's Creative Commons licence and your intended use is not permitted by statutory regulation or exceeds the permitted use, you will need to obtain permission directly from the copyright holder. To view a copy of this licence, visit http://creativecommons. org/licenses/by/4.0/.

\section{References}

Bador M, Terray L, Boé J, Somot S, Alias A, Gibelin A-L, Dubuisson B (2017) Future summer mega-heatwave and record-breaking temperatures in a warmer France climate. Environ Res Lett 12(7):074025. https://doi.org/10.1088/1748-9326/aa751c

Ban N, Schmidli J, Schär C (2014) Evaluation of the convectionresolving regional climate modeling approach in decade-long simulations. J Geophys Res 119(13):7889-7907. https://doi.org/10. 1002/2014JD021478

Bartók B, Wild M, Folini D, Lüthi D, Kotlarski S, Schär C, Vautard R, Jerez S, Imecs Z (2017) Projected changes in surface solar radiation in CMIP5 global climate models and in EUROCORDEX regional climate models for Europe. Clim Dyn 49(78):2665-2683. https://doi.org/10.1007/s00382-016-3471-2
Becker K, Wulfmeyer V, Berger T, Gebel J, Münch W (2013) Carbon farming in hot, dry coastal areas: an option for climate change mitigation. Earth Syst Dyn 4(2):237-251. https://doi.org/10.5194/ esd-4-237-2013

Belda M, Holtanová E, Halenka T, Kalvová J, Hlávka Z (2015) Evaluation of CMIP5 present climate simulations using the Köppen-Trewartha climate classification. Clim Res 64(3):201212. https://doi.org/10.3354/cr01316

Belda M, Holtanová E, Kalvová J, Halenka T (2016) Global warminginduced changes in climate zones based on CMIP5 projections. Clim Res 71(1):17-31. https://doi.org/10.3354/cr01418

Belušić A, Prtenjak MT, Güttler I, Ban N, Leutwyler D, Schär C (2017) Near-surface wind variability over the broader Adriatic region: Insights from an ensemble of regional climate models. Clim Dyn 50(11-12):4455-4480. https://doi.org/10.1007/s00382017-3885-5

Benestad R, Parding K, Dobler A, Mezghani A (2017a) A strategy to effectively make use of large volumes of climate data for climate change adaptation. Clim Serv 6:48-54. https://doi.org/10.1016/j. cliser.2017.06.013

Benestad R, Sillmann J, Thorarinsdottir TL, Guttorp P, d S Mesquita M, Tye MR, Uotila P, Fox Maule C, Thejll P, Drews M, Parding KM (2017b) New vigour involving statisticians to overcome ensemble fatigue. Nat Clim Change 7(10):697-703. https://doi.org/10.1038/nclimate3393

Berckmans J, Hamdi R, Dendoncker N (2019) Bridging the gap between policy-driven land use changes and regional climate projections. J Geophys Res Atmos 124(12):5934-5950. https://doi.org/10.1029/2018JD029207

Berthou S, Kendon EJ, Chan SC, Ban N, Leutwyler D, Schär C, Fosser G (2018) Pan-european climate at convection-permitting scale: a model intercomparison study. Clim Dyn, 1-25. https://doi.org/10. 1007/s00382-018-4114-6

Bogena HR (2016) TERENO: German network of terrestrial environmental observatories. J Large-Scale Res Facilities JLSRF 2:A52. https://doi.org/10.17815/jlsrf-2-98

Böhm U, Kücken M, Ahrens W, Block A, Hauffe D, Keuler K, Rockel B, Will A (2006) CLM - the climate version of LM: brief description and long-term applications. COSMO Newsletter 6:225-235

Brands S, Herrera S, Fernández J, Gutiérrez JM (2013) How well do CMIP5 Earth System Models simulate present climate conditions in Europe and Africa? Clim Dyn 41(3-4):803-817. https://doi.org/ 10.1007/s00382-013-1742-8

Cardoso RM, Soares PMM, Lima DCA, Semedo A (2016) The impact of climate change on the Iberian low-level wind jet: EUROCORDEX regional climate simulation. Tellus, Series A: Dynamic Meteorology and Oceanography, 68:1. https://doi.org/10.3402/ tellussa.v68.29005

Cardoso RM, Soares PMM, Lima DCA, Miranda PMA (2018) Mean and extreme temperatures in a warming climate: EURO CORDEX and WRF regional climate high-resolution projections for Portugal. Clim Dyn 52:129-157 https://doi.org/10.1007/s00382-0184124-4

Casanueva A, Herrera S, Fernández J, Gutiérrez JM (2016a) Towards a fair comparison of statistical and dynamical downscaling in the framework of the EURO-CORDEX initiative. Clim Change 137(3-4):411-426. https://doi.org/10.1007/s10584-016-1683-4

Casanueva A, Kotlarski S, Herrera S, Fernández J, Gutiérrez JM, Boberg F, Colette A, Christensen OB, Goergen K, Jacob D, Keuler K, Nikulin G, Teichmann C, Vautard R (2016b) Daily precipitation statistics in a euro-cordex rcm ensemble: Added value of raw and bias-corrected high-resolution simulations. Clim Dyn 47(3):719_ 737. https://doi.org/10.1007/s00382-015-2865-x

Cattiaux J, Douville H, Peings Y (2013) European temperatures in CMIP5: origins of present-day biases and future uncertainties. 
Clim Dyn 41(11-12):2889-2907. https://doi.org/10.1007/s00382013-1731-y

Cherubini F, Huang B, Hu X, Tölle MH, Strømman AH (2018) Quantifying the climate response to extreme land cover changes in Europe with a regional model. Environ Res Lett 13(7):074002. https://doi.org/10.1088/1748-9326/aac794

Christensen JH, Carter TR, Rummukainen M, Amanatidis G (2007) Evaluating the performance and utility of regional climate models: the PRUDENCE project. Clim Change 81(SUPPL. 1):16. https://doi.org/10.1007/s10584-006-9211-6

Colin J, Déqué M, Radu R, Somot S (2010) Sensitivity study of heavy precipitation in limited area model climate simulations: influence of the size of the domain and the use of the spectral nudging technique. Tellus, Series A: Dynamic Meteorology and Oceanography 62(5):591-604. https://doi.org/10.1111/j.1600-0870.2010.00467.x

Coppola E, Raffaele F, Giorgi F (2018a) Impact of climate change on snow melt driven runoff timing over the Alpine region. Clim Dyn 51:1259-1273. https://doi.org/10.1007/s00382-016-3331-0

Coppola E, Sobolowski S, Pichelli E, Raffaele F, Ahrens B, Anders I, Ban N, Bastin S, Belda M, Belusic D, Caldas-Alvarez A, Cardoso RM, Davolio S, Dobler A, Fernandez J, Fita L, Fumiere Q, Giorgi F, Goergen K, Güttler I, Halenka T, Heinzeller D, Hodnebrog $\varnothing$, Jacob D, Kartsios S, Katragkou E, Kendon E, Khodayar S, Kunstmann H, Knist S, Lavín-Gullón A, Lind P, Lorenz T, Maraun D, Marelle L, van Meijgaard E, Milovac J, Myhre G, Panitz HJ, Piazza M, Raffa M, Raub T, Rockel B, Schär C, Sieck K, Soares PMM, Somot S, Srnec L, Stocchi P, Tölle MH, Truhetz H, Vautard R, de Vries H, Warrach-Sagi K (2018b) A first-of-its-kind multi-model convection permitting ensemble for investigating convective phenomena over europe and the mediterranean. Clim Dyn. https://doi.org/10.1007/s00382-018-4521-8

Croce P, Formichi P, Landi F, Mercogliano P, Bucchignani E, Dosio A, Dimova S (2018) The snow load in Europe and the climate change. Clim Risk Manag 20:138-154. https://doi.org/10.1016/j. crm.2018.03.001

Davin EL, Seneviratne SI, Ciais P, Olioso A, Wang T (2014) Preferential cooling of hot extremes from cropland albedo management. Proc National Academy Sci 111(27):9757-9761. https://doi.org/10.1073/pnas.1317323111

Davin EL, Maisonnave E, Seneviratne SI (2016) Is land surface processes representation a possible weak link in current regional climate models? Environ Res Lett 11(7):074027. https://doi.org/10. 1088/1748-9326/11/7/074027

Davin EL, Rechid D, Breil M, Cardoso RM, Coppola E, Hoffmann P, Jach LL, Katragkou E, de Noblet-Ducoudré N, Radtke K, Raffa, M, Soares PMM, Sofiadis G, Strada S, Strandberg G, Tölle MH, Warrach-Sagi K, Wulfmeyer V (2020) Biogeophysical impacts of forestation in Europe: First results from the LUCAS Regional Climate Model intercomparison. Earth Syst Dyn 11:183200. https://doi.org/10.5194/esd-11-183-2020

de Noblet-Ducoudré N, Boisier J-P, Pitman A, Bonan GB, Brovkin V, Cruz F, Delire C, Gayler V, van den Hurk BJJM, Lawrence PJ, van der Molen MK, Müller C, Reick CH, Strengers BJ, Voldoire A (2012) Determining robust impacts of land-use-induced land cover changes on surface climate over North America and Eurasia: results from the first set of LUCID experiments. J Clim 25(9):3261-3281. https://doi.org/10.1175/jcli-d-11-00338.1

Dee DP, Uppala SM, Simmons AJ, Berrisford P, Poli P, Kobayashi S, Andrae U, Balmaseda MA, Balsamo G, Bauer P, Bechtold P, Beljaars ACM, van de Berg L, Bidlot J, Bormann N, Delsol C, Dragani R, Fuentes M, Geer AJ, Haimberger L, Healy SB, Hersbach H, Hólm EV, Isaksen L, Kållberg P, Köhler M, Matricardi M, McNally AP, Monge-Sanz BM, Morcrette J-J, Park B-K, Peubey C, de Rosnay P, Tavolato C, Thépaut J-N,
Vitart F (2011) The ERA-Interim reanalysis: configuration and performance of the data assimilation system. Quarterly J Royal Meteorol Soc 137(656):553-597. https://doi.org/10.1002/qj.828

Deser C, Knutti R, Solomon S, Phillips AS (2012) Communication of the role of natural variability in future North American climate. Nat Clim Change 2(11):775-779. https://doi.org/10.1038/nclimate 1562

Dilling L, Berggren J (2014) What do stakeholders need to manage for climate change and variability? A document-based analysis from three mountain states in the Western USA. Reg Environ Change 15(4):657-667. https://doi.org/10.1007/s10113-014-0668-y

Domínguez M, Gaertner MA, de Rosnay P, Losada T (2010) A regional climate model simulation over West Africa: parameterization tests and analysis of land-surface fields. Clim Dyn 35(1):249265. https://doi.org/10.1007/s00382-010-0769-3

Domínguez M, Romera R, Sánchez E, Fita L, Fernández J, JiménezGuerrero P, Montávez J, Cabos W, Liguori G, Gaertner M (2013) Present-climate precipitation and temperature extremes over Spain from a set of high resolution RCMs. Clim Res 58(2):149-164. https://doi.org/10.3354/cr01186

Donnelly C, Greuell W, Andersson J, Gerten D, Pisacane G, Roudier P, Ludwig F (2017) Impacts of climate change on European hydrology at 1.5, 2 and 3 degrees mean global warming above preindustrial level. Clim Change 143:13-26. https://doi.org/10. 1007/s10584-017-1971-7

Dosio A (2016) Projections of climate change indices of temperature and precipitation from an ensemble of bias-adjusted highresolution EURO-CORDEX regional climate models. J Geophys Res Atmos 121(10):5488-5511. https://doi.org/10.1002/2015jd 024411

Dyrrdal AV, Stordal F, Lussana C (2017) Evaluation of summer precipitation from EURO-CORDEX fine-scale RCM simulations over Norway. Int J Climatol 38(4):1661-1677. https://doi.org/10. 1002/joc.5287

Fantini A, Raffaele F, Torma C, Bacer S, Coppola E, Giorgi F, Ahrens B, Dubois C, Sanchez E, Verdecchia M (2018) Assessment of multiple daily precipitation statistics in ERAInterim driven Med-CORDEX and EURO-CORDEX experiments against high resolution observations. Clim Dyn 51(3):877-900. https://doi.org/10.1007/s00382-016-3453-4

Fernández J, Frías MD, Cabos WD, Cofiño AS, Domínguez M, Fita L, Gaertner MA, García-Díez M, Gutiérrez JM, JiménezGuerrero P, Liguori G, Montávez JP, Romera R, Sánchez E (2019) Consistency of climate change projections from multiple global and regional model intercomparison projects. Clim Dyn 52(1):1139-1156. https://doi.org/10.1007/s00382-018-4181-8

Frei C (2014) Interpolation of temperature in a mountainous region using nonlinear profiles and non-Euclidean distances. Int $\mathrm{J}$ Climatol 34(5):1585-1605. https://doi.org/10.1002/joc.3786

Frei P, Kotlarski S, Liniger MA, Schär C (2018) Future snowfall in the Alps: projections based on the EURO-CORDEX regional climate models. The Cryosphere 12(1):1-24. https://doi.org/10.5194/tc12-1-2018

Gaertner MÁ, González-Alemán JJ, Romera R, Domínguez M, Gil V, Sánchez E, Gallardo C, Miglietta MM, Walsh KJE, Sein DV, Somot S, Dell'Aquila A, Teichmann C, Ahrens B, Buonomo E, Colette A, Bastin S, van Meijgaard E, Nikulin G (2018) Simulation of medicanes over the Mediterranean Sea in a regional climate model ensemble: impact of oceanatmosphere coupling and increased resolution. Cli Dyn 51:10411057. https://doi.org/10.1007/s00382-016-3456-1

García-Díez M, Fernández J, Vautard R (2015) An RCM multiphysics ensemble over Europe: multi-variable evaluation to avoid error compensation. Clim Dyn 45(11-12):3141-3156. https://doi.org/10.1007/s00382-015-2529-x 
Giorgi F, Coppola E, Solmon F, Mariotti L, Sylla MB, Bi X, Elguindi N, Diro GT, Nair V, Giuliani G, Turuncoglu UU, Cozzini S, Güttler I, O’Brien TA, Tawfik AB, Shalaby A, Zakey AS, Steiner AL, Stordal F, Sloan LC, Brankovic C (2012) RegCM4: model description and preliminary tests over multiple CORDEX domains. Clim Res 52(1):7-29. https://doi.org/10.3354/ cr01018

Giorgi F, Gutowski WJ (2015) Regional dynamical downscaling and the CORDEX Initiative. Annu Rev Environ Res 40:467-490. https: //doi.org/10.1146/annurev-environ-102014-021217

Giorgi F, Jones C, Asrar G (2009) Addressing climate information needs at the regional level: the CORDEX framework. WMO Bull 58(3): $175-183$

Giorgi F, Torma C, Coppola E, Ban N, Schär C, Somot S (2016) Enhanced summer convective rainfall at Alpine high elevations in response to climate warming. Nat Geosci 9(8):584-589. https://doi.org/10.1038/ngeo2761

Giot O, Termonia P, Degrauwe D, De Troch R, Caluwaerts S, Smet G, Berckmans J, Deckmyn A, De Cruz L, De Meutter P, Duerinckx A, Gerard L, Hamdi R, Van den Bergh J, Van Ginderachter M, Van Schaeybroeck B (2016) Validation of the ALARO-0 model within the EURO-CORDEX framework. Geosci Model Dev 9(3):11431152. https://doi.org/10.5194/gmd-9-1143-2016

Gutiérrez JM, Maraun D, Widmann M, Huth R, Hertig E, Benestad R, Roessler O, Wibig J, Wilcke R, Kotlarski S, San Martín D, Herrera S, Bedia J, Casanueva A, Manzanas R, Iturbide M, Vrac M, Dubrovsky M, Ribalaygua J, Pórtoles J, Räty O, Räisänen J, Hingray B, Raynaud D, Casado MJ, Ramos P, Zerenner T, Turco M, Bosshard T, Štěpánek P, Bartholy J, Pongracz R, Keller DE, Fischer AM, Cardoso RM, Soares PMM, Czernecki B, Pagé C (2018) An intercomparison of a large ensemble of statistical downscaling methods over Europe: results from the VALUE perfect predictor cross-validation experiment. Int J Climatol. https://doi.org/ 10.1002/joc.5462

Gutowski JW, Giorgi F, Timbal B, Frigon A, Jacob D, Kang HS, Raghavan K, Lee B, Lennard C, Nikulin G, O'Rourke E, Rixen M, Solman S, Stephenson T, Tangang F (2016) WCRP coordinated regional downscaling experiment (CORDEX): a diagnostic MIP for CMIP6. Geosci Model Dev 9(11):4087-4095. https://doi.org/10.5194/gmd-9-4087-2016

Hauser M, Gudmundsson L, Orth R, Jézéquel A, Haustein K, Vautard R, van Oldenborgh GJ, Wilcox L, Seneviratne SI (2017) Methods and model dependency of extreme event attribution: the 2015 European drought. Earth's Future 5(10):1034-1043. https://doi.org/10.1002/2017EF000612

Heinzeller D, Duda MG, Kunstmann H (2016) Towards convectionresolving, global atmospheric simulations with the Model for Prediction Across Scales (MPAS) v3.1: an extreme scaling experiment. Geosci Model Dev 9(1):77-110. https://doi.org/10.5194/ gmd-9-77-2016

Hertig E, Maraun D, Bartholy J, Pongracz R, Vrac M, Mares I, Gutiérrez JM, Wibig J, Casanueva A, Soares PMM (2018) Comparison of statistical downscaling methods with respect to extreme events over Europe: validation results from the perfect predictor experiment of the COST action VALUE. Int J Climatol. https://doi.org/10.1002/joc.5469

Hiebl J, Frei C (2016) Daily temperature grids for Austria since 1961 - concept, creation and applicability. Theor Appl Climatol 124(1-2):161-178. https://doi.org/10.1007/s00704-015-1411-4

Hiebl J, Frei C (2018) Daily precipitation grids for Austria since 1961-development and evaluation of a spatial dataset for hydroclimatic monitoring and modelling. Theor Appl Climatol 132(1-2):327-345. https://doi.org/10.1007/s00704-017-2093-x

Hosseinzadehtalaei P, Tabari H, Willems P (2018) Precipitation intensity-duration-frequency curves for central Belgium with an ensemble of EURO-CORDEX simulations, and associated uncertainties. Atmos Res 200:1-12. https://doi.org/10.1016/j.atmosres. 2017.09.015

Huebener H, Hoffmann P, Keuler K, Pfeifer S, Ramthun H, Spekat A, Steger C, Warrach-Sagi K (2017) Deriving user-informed climate information from climate model ensemble results. Adv Sci Res 14:261-269. https://doi.org/10.5194/asr-14-261-2017

Ivanov M, Warrach-Sagi K, Wulfmeyer V (2017) Field significance of performance measures in the context of regional climate model evaluation. Part 1: temperature. Theor Appl Climatol 132(12):219-237. https://doi.org/10.1007/s00704-017-2100-2

Jacob D, Elizalde A, Haensler A, Hagemann S, Kumar P, Podzun R, Rechid D, Remedio AR, Saeed F, Sieck K, Teichmann C, Wilhelm C (2012) Assessing the transferability of the regional climate model REMO to different COordinated regional climate downscaling EXperiment (CORDEX) regions. Atmosphere 3(1):181199. https://doi.org/10.3390/atmos3010181

Jacob D, Petersen J, Eggert B, Alias A, Christensen OB, Bouwer LM, Braun A, Colette A, Déqué M, Georgievski G, Georgopoulou E, Gobiet A, Menut L, Nikulin G, Haensler A, Hempelmann N, Jones C, Keuler K, Kovats S, Kröner N, Kotlarski S, Kriegsmann A, Martin E, van Meijgaard E, Moseley C, Pfeifer S, Preuschmann S, Radermacher C, Radtke K, Rechid D, Rounsevell M, Samuelsson P, Somot S, Soussana J-F, Teichmann C, Valentini R, Vautard R, Weber Brn, Yiou P (2014) EURO-CORDEX: new high-resolution climate change projections for European impact research. Reg Environ Change 14(2):563-578. https://doi.org/10.1007/s10113013-0499-2

Jacob D, Kotova L, Teichmann C, Sobolowski SP, Vautard R, Donnelly C, Koutroulis AG, Grillakis MG, Tsanis IK, Damm A, Sakalli A, van Vliet MTH (2018) Climate Impacts in Europe Under $+1.5^{\circ} \mathrm{C}$ Global Warming. Earth's Future 6(2):264-285. https: //doi.org/10.1002/2017ef000710

Jerez S, Tobin I, Vautard R, Montávez JP, López-Romero JM, Thais F, Bartok B, Christensen OB, Colette A, Déqué M, Nikulin G, Kotlarski S, van Meijgaard E, Teichmann C, Wild M (2015) The impact of climate change on photovoltaic power generation in Europe. Nat Commun 6(1):10014. https://doi.org/10.1038/ncom ms 10014

Katragkou E, García-Díez M, Vautard R, Sobolowski S, Zanis P, Alexandri G, Cardoso RM, Colette A, Fernandez J, Gobiet A, Goergen K, Karacostas T, Knist S, Mayer S, Soares PMM, Pytharoulis I, Tegoulias I, Tsikerdekis A, Jacob D (2015) Regional climate hindcast simulations within EURO-CORDEX: evaluation of a WRF multi-physics ensemble. Geosci Model Dev 8(3):603618. https://doi.org/10.5194/gmd-8-603-2015

Keune J, Gasper F, Goergen K, Hense A, Shrestha P, Sulis M, Kollet $S$ (2016) Studying the influence of groundwater representations on land surface-atmosphere feedbacks during the European heat wave in 2003. J Geophys Res Atmos 121(22):13,301-13,325. https://doi.org/10.1002/2016jd025426

Keune J, Sulis M, Kollet S, Siebert S, Wada Y (2018) Human water use impacts on the strength of the continental sink for atmospheric water. Geophys Res Lett 45(9):4068-4076. https://doi.org/10.102 9/2018g1077621

Kew SF, Philip SY, van Oldenborgh GJ, Otto FEL, Vautard R, van der Schrier G, Tebaldi C (2018) Attribution of the exceptional summer heat wave in Southern Europe 2017. Bull Am Meteor Soc. in press

Kjellström E, Bärring L, Nikulin G, Nilsson C, Persson G, Strandberg $G$ (2016) Production and use of regional climate model projections - a Swedish perspective on building climate services. Clim Serv 2-3:15-29. https://doi.org/10.1016/j.cliser.2016.06.004

Kjellström E, Nikulin G, Strandberg G, Christensen OB, Jacob D, Keuler K, Lenderink G, van Meijgaard E, Schär C, Somot S, Sørland SL, Teichmann C, Vautard R (2018) European climate 
change at global mean temperature increases of 1.5 and $2{ }^{\circ} \mathrm{C}$ above pre-industrial conditions as simulated by the EURO-CORDEX regional climate models. Earth Syst Dyn 9(2):459-478. https://doi. org/10.5194/esd-9-459-2018

Knist S, Goergen K, Buonomo E, Christensen OB, Colette A, Cardoso RM, Fealy R, Fernández J, García-Díez M, Jacob D, Kartsios S, Katragkou E, Keuler K, Mayer S, van Meijgaard E, Nikulin G, Soares PMM, Sobolowski S, Szepszo G, Teichmann C, Vautard R, Warrach-Sagi K, Wulfmeyer V, Simmer C (2017) Land-atmosphere coupling in EURO-CORDEX evaluation experiments. J Geophys Res Atmos 122(1):79-103. https://doi.org/10.1002/2016jd025476

Kotlarski S, Keuler K, Christensen OB, Colette A, Déqué M, Gobiet A, Goergen K, Jacob D, Lüthi D, van Meijgaard E, Nikulin G, Schär C, Teichmann C, Vautard R, Warrach-Sagi K, Wulfmeyer V (2014) Regional climate modeling on European scales: a joint standard evaluation of the EURO-CORDEX RCM ensemble. Geosci Model Dev 7(4):1297-1333. https://doi.org/10.5194/gmd-7-12972014

Lawrence D, Vandecar K (2015) Effects of tropical deforestation on climate and agriculture. Nat Clim Change 5(1):27-36. https://doi.org/10.1038/nclimate2430

Lawrence DM, Hurtt GC, Arneth A, Brovkin V, Calvin KV, Jones $\mathrm{AD}$, Jones $\mathrm{CD}$, Lawrence PJ, de Noblet-Ducoudré $\mathrm{N}$, Pongratz J, Seneviratne SI, Shevliakova E (2016) The land use model intercomparison project (LUMIP) contribution to CMIP6: rationale and experimental design. Geosci Model Dev 9(9):29732998. https://doi.org/10.5194/gmd-9-2973-2016

Lawrence BN, Rezny M, Budich R, Bauer P, Behrens Jrg, Carter M, Deconinck W, Ford R, Maynard C, Mullerworth S, Osuna C, Porter A, Serradell K, Valcke S, Wedi N, Wilson S (2018) Crossing the chasm: how to develop weather and climate models for next generation computers? Geosci Model Dev 11(5):1799_ 1821. https://doi.org/10.5194/gmd-11-1799-2018

Lejeune Q, Seneviratne SI, Davin EL (2017) Historical land-cover change impacts on climate: Comparative assessment of LUCID and CMIP5 multimodel experiments. J Clim 30(4):1439-1459. https://doi.org/10.1175/jcli-d-16-0213.1

Lejeune Q, Davin EL, Gudmundsson L, Winckler J, Seneviratne SI (2018) Historical deforestation locally increased the intensity of hot days in northern mid-latitudes. Nat Clim Change 8(5):386390. https://doi.org/10.1038/s41558-018-0131-z

Leutwyler D, Fuhrer O, Lapillonne X, Lüthi D, Schär C (2016) Towards European-scale convection-resolving climate simulations with GPUs: a study with COSMO 4.19. Geosci Model Dev 9(9):3393-3412. https://10.5194/gmd-9-3393-2016

Lhotka O, Kyselý J, Plavcová E (2017) Evaluation of major heat waves' mechanisms in EURO-CORDEX RCMs over Central Europe. Clim Dyn 50(11-12):4249-4262. https://doi.org/10.1007/ s00382-017-3873-9

Lussana C, Saloranta T, Skaugen T, Magnusson J, Einar Tveito O, Andersen J (2018) SeNorge2 daily precipitation, an observational gridded dataset over Norway from 1957 to the present day. Earth Syst Sci Data 10(1):235-249. https://doi.org/10.5194/essd-10235-2018

Luu LN, Vautard R, Yiou P, van Oldenborgh GJ, Lenderink G (2018) Attribution of extreme rainfall events in the South of France using EURO-CORDEX simulations. Geophysical Research Letters. https://doi.org/10.1029/2018g1077807

Lüthi S, Ban N, Kotlarski S, Steger CR, Jonas T, Schär C (2019) Projections of alpine snow-cover in a high-resolution climate simulation. Atmosphere 10(8):463. https://doi.org/10.3390/atmos1008 0463, https://www.mdpi.com/2073-4433/10/8/463

Maraun D, Huth R, Gutiérrez JM, Martín DS, Dubrovsky M, Fischer A, Hertig E, Soares PMM, Bartholy J, Pongrácz R, Widmann M,
Casado MJ, Ramos P, Bedia J (2017) The VALUE perfect predictor experiment: evaluation of temporal variability. International Journal of Climatology. https://doi.org/10.1002/joc.5222

Maraun D, Widmann M, Gutiérrez JM, Kotlarski S, Chandler RE, Hertig E, Wibig J, Huth R, Wilcke RAI (2015) VALUE: a framework to validate downscaling approaches for climate change studies. Earth's Future 3(1):1-14. https://doi.org/10.1002/2014ef000259

Maraun D, Widmann M, Gutierrez JM (2018) Statistical downscaling skill under present climate conditions: a synthesis of the VALUE perfect predictor experiment. International Journal of Climatology. https://doi.org/10.1002/joc.5877

McSweeney CF, Jones RG, Lee RW, Rowell DP (2014) Selecting CMIP5 GCMs for downscaling over multiple regions. Clim Dyn 44(11-12):3237-3260. https://doi.org/10.1007/s00382-0142418-8

Mendlik T, Gobiet A (2015) Selecting climate simulations for impact studies based on multivariate patterns of climate change. Clim Change 135(3-4):381-393. https://doi.org/10.1007/s10584-015$1582-0$

Mezghani A, Dobler A, Haugen JE, Benestad RE, Parding KM, Piniewski M, Kardel I, Kundzewicz ZW (2017) CHASE-PL climate projection dataset over Poland - bias adjustment of EURO-CORDEX simulations. Earth Syst Sci Data 9(2):905-925. https://doi.org/10.5194/essd-9-905-2017

Mezghani A, Dobler A, Benestad R, Haugen JE, Parding KM, Piniewski M, Kundzewicz ZW (2019) Subsampling impact on the climate change signal over Poland based on simulations from statistical and dynamical downscaling. J Appl Meteorol Climatol 58(5):1061-1078. https://doi.org/10.1175/JAMC-D-18-0179.1

Moemken J, Reyers M, Feldmann H, Pinto JG (2018) Future changes of wind speed and wind energy potentials in EURO-CORDEX ensemble simulations. J Geophys Res Atmos 123(12):6373-6389. https://doi.org/10.1029/2018JD028473

Ouzeau G, Soubeyroux J-M, Schneider M, Vautard R, Planton S (2016) Heat waves analysis over France in present and future climate: Application of a new method on the EURO-CORDEX ensemble. Clim Serv 4:1-12. https://doi.org/10.1016/j.cliser.2016. 09.002

Perugini L, Caporaso L, Marconi S, Cescatti A, Quesada B, de NobletDucoudré N, House JI, Arneth A (2017) Biophysical effects on temperature and precipitation due to land cover change. Environ Res Lett 12(5):053002. https://doi.org/10.1088/1748-9326/aa6b3f

Philip S, Kew SF, van Oldenborgh GJ, Aalbers E, Vautard R, Otto F, Haustein K, Habets F, Singh R (2018) Validation of a rapid attribution of the May/June 2016 flood-inducing precipitation in France to climate change. Journal of Hydrometeorology. https://doi.org/10.1175/jhm-d-18-0074.1

Pielke RA, Pitman A, Niyogi D, Mahmood R, McAlpine C, Hossain F, Klein Goldewijk K, Nair U, Betts R, Fall S, Reichstein M, Kabat P, de Noblet N (2011) Land use/land cover changes and climate: modeling analysis and observational evidence. Wiley Interdiscip Rev Clim Change 2(6):828-850. https://doi.org/10.1002/wcc. 144

Pitman AJ, de Noblet-Ducoudré N, Avila FB, Alexander LV, Boisier J-P, Brovkin V, Delire C, Cruz F, Donat MG, Gayler V, van den Hurk B, Reick C, Voldoire A (2012) Effects of land cover change on temperature and rainfall extremes in multi-model ensemble simulations. Earth Syst Dyn 3(2):213-231. https://doi.org/10. 5194/esd-3-213-2012

Prein AF, Langhans W, Fosser G, Ferrone A, Ban N, Goergen K, Keller M, Tölle M, Gutjahr O, Feser F, Brisson E, Kollet S, Schmidli J, van Lipzig NPM, Leung R (2015) A review on regional convection-permitting climate modeling: demonstrations, prospects, and challenges. Rev Geophys 53(2):323-361. https://doi.org/10.1002/2014rg000475 
Prein AF, Gobiet A (2016) Impacts of uncertainties in European gridded precipitation observations on regional climate analysis. Int J Climatol 37(1):305-327. https://doi.org/10.1002/joc.4706

Prein AF, Liu C, Ikeda K, Bullock R, Rasmussen RM, Holland GJ, Clark M (2017a) Simulating north american mesoscale convective systems with a convection-permitting climate model. Clim Dyn 28:1-16. https://doi.org/10.1007/s00382-017-3993-2

Prein AF, Rasmussen R, Stephens G (2017b) Challenges and advances in convection-permitting climate modeling. Bull Am Meteorol Soc 98(5):1027-1030. https://doi.org/10.1175/bams-d-16-0263.1

Púčik T, Groenemeijer P, Rädler AT, Tijssen L, Nikulin G, Prein AF, van Meijgaard E, Fealy R, Jacob D, Teichmann C (2017) Future changes in European severe convection environments in a regional climate model ensemble. J Clim 30(17):6771-6794. https://doi.org/10.1175/jcli-d-16-0777.1

Rajczak J, Schär C (2017) Projections of future precipitation extremes over Europe: a multimodel assessment of climate simulations. $\mathbf{J}$ Geophys Res Atmos 122(20):10,773-10,800. https://doi.org/10. 1002/2017jd027176

Raymond F, Ullmann A, Tramblay Y, Drobinski P, Camberlin P (2019) Evolution of mediterranean extreme dry spells during the wet season under climate change. Reg Environ Change. https://doi. org/10.1007/s10113-019-01526-3

Reder A, Iturbide M, Herrera S, Rianna G, Mercogliano P, Gutiérrez JM (2018) Assessing variations of extreme indices inducing weather-hazards on critical infrastructures over Europe-the INTACT framework. Clim Change 148(1-2):123-138. https://doi. org/10.1007/s10584-018-2184-4

Rockel B, Will A, Hense A (2008) The regional climate model COSMO-CLM (CCLM). Meteorologische Zeitschrift 17(4):347348

Ruane AC, Teichmann C, Arnell NW, Carter TR, Ebi KL, Frieler $\mathrm{K}$, Goodess CM, Hewitson B, Horton R, Kovats RS, Lotze HK, Mearns LO, Navarra A, Ojima DS, Riahi K, Rosenzweig C, Themessl M, Vincent K (2016) The vulnerability, impacts, adaptation and climate services advisory board (VIACS AB v1.0) contribution to CMIP6. Geosci Model Dev 9(9):3493-3515. https://doi.org/10.5194/gmd-9-3493-2016

Rulfová Z, Beranová R, Kyselý J (2016) Climate change scenarios of convective and large-scale precipitation in the Czech Republic based on EURO-CORDEX data. Int J Climatol 37(5):2451-2465. https://doi.org/10.1002/joc.4857

Ruti PM, Somot S, Giorgi F, Dubois C, Flaounas E, Obermann A, Dell'Aquila A, Pisacane G, Harzallah A, Lombardi E, Ahrens B, Akhtar N, Alias A, Arsouze T, Aznar R, Bastin S, Bartholy J, Béranger K, Beuvier J, Bouffies-Cloché S, Brauch J, Cabos W, Calmanti S, Calvet J-C, Carillo A, Conte D, Coppola E, Djurdjevic V, Drobinski P, Elizalde-Arellano A, Gaertner $\mathrm{M}$, Galàn $\mathrm{P}$, Gallardo $\mathrm{C}$, Gualdi $\mathrm{S}$, Goncalves $\mathrm{M}$, Jorba $\mathrm{O}$, Jordà G, L'Heveder B, Lebeaupin-Brossier C, Li L, Liguori G, Lionello $\mathrm{P}$, Maciàs $\mathrm{D}$, Nabat $\mathrm{P}$, nol $\mathrm{B}$, Raikovic $\mathrm{B}$, Ramage K, Sevault F, Sannino G, Struglia MV, Sanna A, Torma C, Vervatis V (2016) Med-CORDEX initiative for mediterranean climate studies. Bull Am Meteorol Soc 97(7):1187-1208. https://doi.org/10.1175/bams-d-14-00176.1

Samuelsson P, Jones CG, Willén U, Ullerstig A, Gollvik S, Hansson U, Jansson C, Kjellström E, Nikulin G, Wyser K (2011) The Rossby Centre regional climate model RCA3: model description and performance. Tellus A: Dynamic Meteorology and Oceanography 63(1):4-23. https://doi.org/10.1111/j.1600-0870.2010.00478.x

Santanello JA, Dirmeyer PA, Ferguson CR, Findell KL, Tawfik AB, Berg A, Ek M, Gentine P, Guillod BP, van Heerwaarden C, Roundy J, Wulfmeyer V (2018) Land-atmosphere interactions: the LoCo perspective. Bull Am Meteorol Soc 99(6):1253-1272. https://doi.org/10.1175/bams-d-17-0001.1
Scaff L, Prein AF, Li Y, Liu C, Rasmussen R, Ikeda K (2019) Simulating the convective precipitation diurnal cycle in north america's current and future climate. Climate Dynamics. https://doi.org/10.1007/s00382-019-04754-9

Schwitalla T, Bauer HS, Wulfmeyer V, Warrach-Sagi K (2017) Continuous high-resolution midlatitude-belt simulations for JulyAugust 2013 with WRF. Geosci Model Dev 10(5):2031-2055. https://doi.org/10.5194/gmd-10-2031-2017

Skamarock WC, Klemp JB (2008) A time-split nonhydrostatic atmospheric model for weather research and forecasting applications. J Comput Phys 227(7):3465-3485. https://doi.org/10.1016/j.jcp. 2007.01.037

Smiatek G, Kunstmann H, Senatore A (2016) EURO-CORDEX regional climate model analysis for the greater alpine region: performance and expected future change. J Geophys Res Atmos 121(13):7710-7728. https://doi.org/10.1002/2015jd024727

Soares PMM, Cardoso RM (2017) A simple method to assess the added value using high-resolution climate distributions: application to the EURO-CORDEX daily precipitation. Int $\mathrm{J}$ Climatol 38(3):1484-1498. https://doi.org/10.1002/joc.5261

Soares PMM, Maraun D, Brands S, Jury MW, Gutiérrez JM, San Martin D, Hertig E, Huth R, Belušić A, Cardoso RM, Kotlarski S, Drobinski P, Obermann-Hellhund A (2018) Processbased evaluation of the VALUE perfect predictor experiment of statistical downscaling methods. Int J Climatol 39:3868-3893. https://doi.org/10.1002/joc.5911. https://rmets.onlinelibrary.wiley. com/doi/pdf/10.1002/joc.5911

Somot S, Ruti P, Ahrens B, Coppola E, Jordà G, Sannino G, Solmon F (2018) Editorial for the Med-CORDEX special issue. Clim Dyn 51(3):771-777. https://doi.org/10.1007/s00382-018-4325-x

Sørland SL, Schär C, Lüthi D, Kjellström E (2018) Bias patterns and climate change signals in GCM-RCM model chains. Environ Res Lett 13(7):074017. https://doi.org/10.1088/1748-9326/aacc77

Stepanek P, Zahradníček P, Farda A, Skalák P, Trnka M, Meitner J, Rajdl K (2016) Projection of drought-inducing climate conditions in the Czech Republic according to euro-CORDEX models. Clim Res 70(2-3):179-193. https://doi.org/10.3354/cr01424

Stott PA, Christidis N, Otto FEL, Sun Y, Vanderlinden JP, van Oldenborgh GJ, Vautard R, von Storch H, Walton P, Yiou P, Zwiers FW (2015) Attribution of extreme weather and climaterelated events. Wiley Interdiscip Rev Clim Change 7(1):23-41. https://doi.org/10.1002/wcc.380

Teichmann C, Bülow K, Otto J, Pfeifer S, Rechid D, Sieck K, Jacob D (2018) Avoiding Extremes: Benefits of Staying below $+1.5^{\circ} \mathrm{C}$ Compared to $+2.0^{\circ} \mathrm{C}$ and $+3.0^{\circ} \mathrm{C}$ Global Warming. Atmosphere 9(4):115. https://doi.org/10.3390/atmos9040115

Termonia P, Van Schaeybroeck B, De Cruz L, De Troch R, Caluwaerts S, Giot O, Hamdi R, Vannitsem S, Duchêne F, Willems P, Tabari H, Van Uytven E, Hosseinzadehtalaei P, Van Lipzig N, Wouters $H$, Vanden Broucke S, van Ypersele J-P, Marbaix P, VillanuevaBirriel C, Fettweis X, Wyard C, Scholzen C, Doutreloup S, De Ridder K, Gobin A, Lauwaet D, Stavrakou T, Bauwens M, Müller J-F, Luyten P, Ponsar S, Van den Eynde D, Pottiaux E (2018) The CORDEX.be initiative as a foundation for climate services in Belgium. Climate Services. https://doi.org/10.1016/j.cliser.2018.05. 001

Thiery W, Davin EL, Lawrence DM, Hirsch AL, Hauser M, Seneviratne SI (2017) Present-day irrigation mitigates heat extremes. J Geophys Res Atmos 122(3):1403-1422. https://doi.org/10.1002/2016jd025740

Tobin I, Jerez S, Vautard R, Thais F, van Meijgaard E, Prein A, Déqué M, Kotlarski S, Fox Maule C, Nikulin G, Noël T, Teichmann C (2016) Climate change impacts on the power generation potential of a European mid-century wind farms scenario. Environ Res Lett 11(3):034013. http://stacks.iop.org/1748-9326/11/i=3/a=034013 
Tobin I, Greuell W, Jerez S, Ludwig F, Vautard R, van Vliet MTH, Bréon FM (2018) Vulnerabilities and resilience of European power generation to $1.5{ }^{\circ} \mathrm{C}, 2{ }^{\circ} \mathrm{C}$ and $3{ }^{\circ} \mathrm{C}$ warming. Environ Res Lett 13(4):044024. http://stacks.iop.org/1748-9326/13/i=4/ $\mathrm{a}=044024$

Torma C, Giorgi F, Coppola E (2015) Added value of regional climate modeling over areas characterized by complex terrainprecipitation over the Alps. J Geophys Res Atmos 120(9):39573972. https://doi.org/10.1002/2014jd022781

Tramblay Y, Somot S (2018) Future evolution of extreme precipitation in the mediterranean. Clim Change 151(2):289-302. https://doi.org/10.1007/s10584-018-2300-5

Turco M, Sanna A, Herrera S, Llasat MC, Gutiérrez JM (2013) Large biases and inconsistent climate change signals in ENSEMBLES regional projections. Clim Change 120(4):859-869. https://doi.org/10.1007/s10584-013-0844-y

van der Linden P, Mitchell JFB (2009) ENSEMBLES: Climate change and its impacts - summary of research and results from the ENSEMBLES project. Tech. rep., Met Office Hadley Centre, Exeter, United Kingdom. http://mfkp.org/INRMM/article/ 14257308

Van Meijgaard E, Van Ulft L, Lenderink G, De Roode S, Wipfler EL, Boers R, van Timmermans R (2012) Refinement and application of a regional atmospheric model for climate scenario calculations of western europe. KVR 054/12 KVR

Vautard R, Gobiet A, Jacob D, Belda M, Colette A, Déqué M, Fernández J, García-Díez M, Goergen K, Güttler I, Halenka T, Karacostas T, Katragkou E, Keuler K, Kotlarski S, Mayer S, van Meijgaard E, Nikulin G, Patarčić M, Scinocca J, Sobolowski S, Suklitsch M, Teichmann C, Warrach-Sagi K, Wulfmeyer V, Yiou P (2013) The simulation of European heat waves from an ensemble of regional climate models within the EURO-CORDEX project. Clim Dyn 41(9-10):2555-2575. https://doi.org/10.1007/s00382013-1714-z

Vautard R, Colette A, van Meijgaard E, Meleux F, van Oldenborgh GJ, Otto F, Tobin I, Yiou P (2018) 14. Attribution of wintertime anticyclonic stagnation contributing to air pollution in western Europe.
Bull Am Meteorol Soc 99(1):S70-S75. https://doi.org/10.1175/ BAMS-D-17-0113.1

Vautard R, Jan Van Oldenborgh G, Otto FEL, Yiou P, De Vries H, Van Meijgaard E, Stepek A, Soubeyroux J-M, Philip S, Kew SF, Costella C, Singh R, Tebaldi C (2019) Human influence on european winter wind storms such as those of January 2018. Earth Syst Dyn 10(2):271-286. https://doi.org/10.5194/esd-10-271-2019

Warrach-Sagi K, Schwitalla T, Wulfmeyer V, Bauer H-S (2013) Evaluation of a climate simulation in Europe based on the WRF-NOAH model system: precipitation in Germany. Clim Dyn 41(3-4):755-774. https://doi.org/10.1007/s00382-013-1727-7

WCRP Joint Scientific Committee (JSC) (2019) World Climate Research Programme Strategic Plan 2019-2028. WCRP Publication $1 / 2019$

Widmann M, Bedia J, Gutiérrez JM, Bosshard T, Hertig E, Maraun D, Casado MJ, Ramos P, Cardoso RM, Soares PMM, Ribalaygua J, Pagé C, Fischer AM, Herrera S, Huth R (2019) Validation of spatial variability in downscaling results from the VALUE perfect predictor experiment. Int J Climatol 39(9):3819-3845. https://doi.org/10.1002/joc.6024

Will A, Akhtar N, Brauch J, Breil M, Davin E, Ho-Hagemann HTM, Maisonnave E, Thürkow M, Weiher S (2017) The COSMOCLM 4.8 regional climate model coupled to regional ocean, land surface and global earth system models using OASIS3-MCT: description and performance. Geosci Model Dev 10(4):15491586. https://doi.org/10.5194/gmd-10-1549-2017

Wulfmeyer V, Turner DD, Baker B, Banta R, Behrendt A, Bonin T, Brewer WA, Buban M, Choukulkar A, Dumas R, Hardesty $\mathrm{RM}$, Heus $\mathrm{T}$, Ingwersen $\mathrm{J}$, Lange $\mathrm{D}$, Lee TR, Metzendorf S, Muppa SK, Meyers T, Newsom R, Osman M, Raasch S, Santanello J, Senff C, SpäTh F, Wagner T, Weckwerth T (2018) A new research approach for observing and characterizing landatmosphere feedback. Bull Am Meteorol Soc 99(8):1639-1667. https://doi.org/10.1175/BAMS-D-17-0009.1

Publisher's note Springer Nature remains neutral with regard to jurisdictional claims in published maps and institutional affiliations. 


\section{Affiliations}

Daniela Jacob $^{1}$ - Claas Teichmann ${ }^{1}$ (D) - Stefan Sobolowski ${ }^{2} \cdot$ Eleni Katragkou $^{3} \cdot$ Ivonne Anders $^{4} \cdot$ Michal Belda $^{5}$. Rasmus Benestad $^{6}$ - Fredrik Boberg ${ }^{7}$ - Erasmo Buonomo ${ }^{8,9}$ • Rita M. Cardoso ${ }^{10}$. Ana Casanueva ${ }^{11}$.

Ole B. Christensen ${ }^{7}$. Jens Hesselbjerg Christensen ${ }^{2,12}$. Erika Coppola ${ }^{13}$ • Lesley De Cruz ${ }^{14}$. Edouard L. Davin ${ }^{15}$. Andreas Dobler $^{6} \cdot$ Marta Domínguez $^{16}$ - Rowan Fealy ${ }^{17} \cdot$ Jesus Fernandez $^{11}$. Miguel Angel Gaertner ${ }^{18}$. Markel García-Díez ${ }^{11}$ - Filippo Giorgi ${ }^{13}$ - Andreas Gobiet $^{4}$ • Klaus Goergen ${ }^{19,20}$ - Juan José Gómez-Navarro ${ }^{21}$. Juan Jesús González Alemán ${ }^{18}$. Claudia Gutiérrez ${ }^{18}$ • José M. Gutiérrez ${ }^{22}$ • Ivan Güttler ${ }^{23}$ - Andreas Haensler ${ }^{1}$. Tomáš Halenka $^{5}$ - Sonia Jerez ${ }^{21}$ • Pedro Jiménez-Guerrero ${ }^{21} \cdot$ Richard G. Jones $^{8}$. Klaus Keuler ${ }^{24} \cdot$ Erik Kjellström $^{25}$. Sebastian Knist $^{20,26}$ - Sven Kotlarski ${ }^{27}$. Douglas Maraun ${ }^{28}$. Erik van Meijgaard ${ }^{29}$ - Paola Mercogliano ${ }^{30,31}$. Juan Pedro Montávez 21 . Antonio Navarra ${ }^{30}$. Grigory Nikulin ${ }^{25}$. Nathalie de Noblet-Ducoudré ${ }^{32}$.

Hans-Juergen Panitz ${ }^{33}$ - Susanne Pfeifer ${ }^{1}$ - Marie Piazza ${ }^{28}$. Emanuela Pichelli ${ }^{13}$ - Joni-Pekka Pietikäinen ${ }^{1,34}$.

Andreas F. Prein ${ }^{35}$ - Swantje Preuschmann ${ }^{1}$ - Diana Rechid ${ }^{1}$ - Burkhardt Rockel ${ }^{36}$ - Raquel Romera ${ }^{17}$.

Enrique Sánchez $^{17} \cdot$ Kevin Sieck $^{1} \cdot$ Pedro M. M. Soares $^{10} \cdot$ Samuel Somot $^{37} \cdot$ Lidija Srnec $^{23} \cdot$ Silje Lund Sørland $^{15}$.

Piet Termonia $^{14,38}$. Heimo Truhetz ${ }^{28}$. Robert Vautard ${ }^{32}$. Kirsten Warrach-Sagi ${ }^{39}$ • Volker Wulfmeyer ${ }^{39}$

1 Climate Service Center Germany (GERICS), Helmholtz-Zentrum Geesthacht, Fischertwiete 120095 Hamburg, Germany

2 NORCE Norwegian Research Centre, The Bjerknes Centre for Climate Research, Bergen, Norway

3 Department of Meteorology and Climatology, School of Geology, Aristotle University of Thessaloniki, Thessaloniki, Greece

4 Central Institute for Meteorology and Geodynamics (ZAMG), Vienna, Austria

5 Department of Atmospheric Physics, Faculty of Mathematics and Physics, Charles University, Prague, Czech Republic

6 The Norwegian Meteorological Institute, Oslo, Norway

7 Danish Meteorological Institute (DMI), Copenhagen, Denmark

8 Met Office Hadley Centre, Fitzroy Road, Exeter, EX1 2HF, UK

9 School of Geography and the Environment, University of Oxford, South Parks Road, Oxford, OX1 3QY, UK

10 Instituto Dom Luiz (IDL), Faculdade de Ciências, Universidade de Lisboa, 1749-016 Lisbon, Portugal

11 Meteorology Group, Department of Applied Mathematics and Computer Science, Universidad de Cantabria, Santander, Spain

12 Niels Bohr Institute, University of Copenhagen, Copenhagen, Denmark

13 International Centre for Theoretical Physics (ICTP), Trieste, Italy

14 Royal Meteorological Institute of Belgium (RMIB), Brussels, Belgium

15 Institute for Atmospheric and Climate Science, ETH Zurich, Zurich, Switzerland

16 Agencia Estatal de Meteorología, Madrid, Spain

17 ICARUS, Department of Geography, Maynooth University, Maynooth, Co. Kildare, Ireland

18 University of Castilla-La Mancha, Toledo, Spain

19 Institute of Bio- and Geosciences, Agrosphere (IBG-3), Research Centre Jülich, Jülich, Germany

20 Centre for High-Performance Scientific Computing in Terrestrial Systems, Geoverbund ABC/J, Jülich, Germany
21 Regional Atmospheric Modeling Group, Department of Physics, University of Murcia, Murcia, Spain

22 Meteorology Group, Instituto de Física de Cantabria (CSICUniversidad de Cantabria), Santander, Spain

23 Croatian Meteorological and Hydrological Service, Zagreb, Croatia

24 Chair of Atmospheric Processes, Brandenburg University of Technology Cottbus - Senftenberg, Cottbus, Germany

25 Swedish Meteorological and Hydrological Institute, Norrköping, Sweden

26 Meteorological Institute, University of Bonn, Bonn, Germany

27 Federal Office of Meteorology and Climatology MeteoSwiss, Zurich-Airport, Switzerland

28 Wegener Center for Climate and Global Change, University of Graz, Graz, Austria

29 Royal Netherlands Meteorological Institute (KNMI), De Bilt, The Netherlands

30 Centro Euro-Mediterraneo sui Cambiamenti Climatici (CMCC), Lecce, Italy

31 C.I.R.A., Capua, Italy

32 Laboratoire des Sciences du Climat et de l'Environnement, IPSL, Unité Mixte CEA-CNRS-UVSQ, Université Paris-Saclay, Orme des Merisiers, 91191 Gif-sur-Yvette cédex, France

33 Institute of Meteorology and Climate Research, Karlsruhe Institute of Technology, Karlsruhe, Germany

34 Finnish Meteorological Institute (FMI), Helsinki, Finland

35 National Center for Atmospheric Research, Boulder, CO, USA

36 Helmholtz-Zentrum Geesthacht, Geesthacht, Germany

37 CNRM, Université de Toulouse, Météo-France, CNRS, Toulouse, France

38 Department of Physics and Astronomy, Ghent University, Ghent, Belgium

39 Institute of Physics and Meteorology, University of Hohenheim, Stuttgart, Germany 